\title{
Exergy Evaluation of Desalination Processes
}

\author{
Veera Gnaneswar Gude \\ Department of Civil and Environmental Engineering, Mississippi State University, \\ Mississippi State, MS 39762, USA; gude@cee.msstate.edu
}

Received: 31 March 2018; Accepted: 6 June 2018; Published: 14 June 2018

\begin{abstract}
Desalination of sea or brackish water sources to provide clean water supplies has now become a feasible option around the world. Escalating global populations have caused the surge of desalination applications. Desalination processes are energy intensive which results in a significant energy portfolio and associated environmental pollution for many communities. Both electrical and heat energy required for desalination processes have been reduced significantly over the recent years. However, the energy demands are still high and are expected to grow sharply with increasing population. Desalination technologies utilize various forms of energy to produce freshwater. While the process efficiency can be reported by the first law of thermodynamic analysis, this is not a true measure of the process performance as it does not account for all losses of energy. Accordingly, the second law of thermodynamics has been more useful to evaluate the performance of desalination systems. The second law of thermodynamics (exergy analysis) accounts for the available forms of energy in the process streams and energy sources with a reference environment and identifies the major losses of exergy destruction. This aids in developing efficient desalination processes by eliminating the hidden losses. This paper elaborates on exergy analysis of desalination processes to evaluate the thermodynamic efficiency of major components and process streams and identifies suitable operating conditions to minimize exergy destruction. Well-established MSF, MED, MED-TVC, $\mathrm{RO}$, solar distillation, and membrane distillation technologies were discussed with case studies to illustrate the exergy performances.
\end{abstract}

Keywords: desalination; energy; exergy; entropy; environment; sustainability

\section{Introduction}

Freshwater is an essential commodity for sustaining human life on earth [1]. World population has tripled during the past century while the water withdrawal rates increased by six times for various uses [2]. Increasing population, rapid industrialization followed by urbanization and high living standards are the causes for this increased water withdrawals around the world. Many regions in the world are not able to meet the ever-increasing water demands due to both diminishing water resources and impairment of available surface and ground water sources leaving desalination as an option of freshwater supplies [3]. Desalination processes require large quantities of energy for water purification which are significantly higher than the energy requirements by conventional surface water treatment processes $[4,5]$. This energy is usually supplied both in the form of thermal and electrical energy. The energy-intensive nature of desalination processes places concomitant demand for energy sources as well. This situation can be termed as "water for oil" [3]. While the energy requirements for desalination processes can be met by various energy sources, many countries that lack water sources also lack conventional energy sources such as fossil fuels. This situation creates a need for efficient use of available energy sources for other beneficial processes as well as careful allocation of energy sources for freshwater production. This can be done by efficient process design, energy conservation, utilization and techno-economic analysis, and development of the systems under study. While the first 
law of thermodynamics has been conveniently used to quantify the energy efficiencies of a process, it does not provide a true measure of process efficiency since the energy supplied to a system can never be recovered in its original form or quality. Energy is transformed or converted into other forms in the process of utilization.

In process development, especially in thermal systems, a common phrase that is widely used is "energy consumption" of delivering a product. While this term seems to be clear and sensible, the actual meaning and the understanding of "energy consumption" is not true. This is because according to the first law of thermodynamics, energy can neither be created nor destroyed, rather it is a conservative property. This means that energy can never be consumed or lost, however, energy can be transformed into other forms. Its quality may be degraded as the work is produced or converted into other forms but it is never lost or destroyed. For this reason it would be convenient to say "energy transformed" or more meaningfully "energy utilized" rather than "energy consumed". However, the degradation in quality or availability of work should be properly accounted which is called exergy. Exergy is part of the energy embedded in a substance that can be transformed into other forms [6]. Exergy is also known as the quality of the work that could be performed by an energy source. Therefore, the first law of thermodynamics refers to the energy efficiency which is more of a quantitative term while the second law of thermodynamics refers to the quality of energy.

Exergy is defined as the quantity of available work in a reversible process when some matter is allowed to reach a state of thermodynamic equilibrium with its surrounding nature. This means, exergy of a system represents the maximum amount of available work at a certain thermodynamic state with reference to its surroundings. Exergy is actually related to ideal work. It should also be emphasized that there is a strong link between exergy and entropy since entropy production is equivalent to exergy loss, which again is equivalent to lost work. Therefore, exergy is the ability to produce work and entropy is the system's inability to do work.

\section{Energy, Entropy, and Exergy Relationship}

While energy cannot be lost, exergy can be lost or consumed (i.e., destroyed) [7-9]. Exergy consumed is converted to entropy. When heat transfer occurs between two bodies from the hot side $\left(T_{1}\right)$ to the cold side $\left(T_{2}\right)$, energy transfer takes place at the expense of a thermal gradient. Although an energy efficiency of $100 \%$ can be achieved between the two bodies, the resultant body temperature may not be same as the source from which the heat transfer occurred, or it may occur at an infinite time scale or it may never happen due to unavoidable ambient losses. This means degradation of energy occurred in this process of heat transfer which is often expressed as generation of entropy. As a result of entropy generation, the quality of energy transferred from the source to the sink is reduced which is reflected by the availability of energy in the sink (the body to which energy is being transferred). This degradation in the quality of energy is called exergy loss (availability loss). The exergy loss is also called irreversibility [8].

Different forms of energy have different capacities to do work. For example, potential energy, kinetic energy, and work energy can be converted completely to work, whereas only a fraction of heat energy can be converted to work while the remainder has to be rejected to the surroundings. The property exergy serves as a measure of the ability of energy to do work; it is equal to the maximum amount of work that can be extracted from a given quantity of energy $\left(W_{\max }\right)$. Thus, the exergy, $E$, associated with a given quantity of heat energy, $Q$, at a temperature of $T$ can be derived from the Carnot efficiency $\left(\eta_{\text {carnot }}\right)$ of a reversible heat engine working between $T$ and the surroundings temperature, $T_{0}$ :

$$
E=W_{\max }=\eta_{\text {carnot }} Q=\left[1-\frac{T_{0}}{T}\right] Q
$$


From Equation (1), the exergy factor of a given quantity of heat energy, $Q$ can be written as (see Figure 1):

$$
\frac{E}{Q}=\left[1-\frac{T_{0}}{T}\right]
$$

Energy is always conserved, but exergy is conserved only in reversible processes. Since all real processes are irreversible, their exergy output is usually less than the exergy input. The exergy output of a process includes utilized output and unutilized output, which is the exergy flow into the environment. The total loss of exergy in a process thus includes the loss due to irreversibility and the loss due to waste streams. Exergy is that part of energy that can be transformed into other forms of energy. It is the useful energy of a system in its environment, i.e., the maximum quantity of work that the system can execute in its environment [10]. For example, exergy for a flow stream consists of three essential components; temperature, pressure, and concentration, which have been used in exergy analysis of various systems including membrane processes [10,11].

The impetus for new tools for a comprehensive and accurate analysis of industrial and energy utilization systems comes from the need for sustainable development that could be impeded by exhausting energy sources and deteriorating environment. Exergy evaluation provides insight to achieve highest technological efficiency at the lowest cost while meeting the social and legal conditions. Exergy analysis is generally carried through various stages of process development including design phase and when evaluating economic feasibility of a system [12]. It is very critical in estimating the process economics, natural resource utilization and environmental impacts of a system because exergy performance depends on the environmental conditions (temperature and pressure) [12,13]. Other process applications include exergy analysis of waste heat and solar energy utilization in desalination, nuclear desalination and air-conditioning systems [8,11-19]. Exergy analysis identifies pathways to increase energy efficiency in a system, which benefits the environment by avoiding excess energy use, associated resource consumption, and environmental pollution. Improving energy efficiency increases both economic and environmental benefits [9].

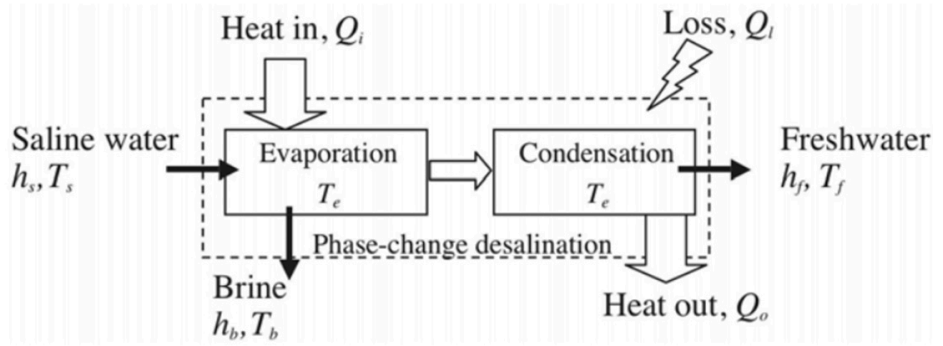

Figure 1. Generic phase-change desalination process with energy flows [19].

\section{Desalination Processes and Operation Principles}

Desalination processes are based on two major principles: (1) evaporation/condensation and (2) separation or filtration [1,2]. An evaporation process requires thermal energy to form pure water vapor from a saline water source which is being heated. This water vapor is condensed on a cooling surface to collect as freshwater. A small portion of electrical energy is required for fluid transfer and to create high or low pressures suitable for evaporation process. A separation process involves a membrane which acts as a physical barrier to separate water molecules from saline water via permeation or diffusion. Thermal- or evaporation-based desalination is the separation principle for solar distillation or solar stills; multi-effect evaporation/distillation (MED); multi-stage flash distillation (MSF); thermal vapor compression (TVC); and mechanical vapor compression (MVC). Electrodialysis (ED) and reverse osmosis (RO) are the predominant membrane based desalination processes. Other emerging desalination processes are membrane distillation (MD) and reverse osmosis combined with MSF or MED processes [2]. Details of working principles are discussed elsewhere [1,2]. 


\section{Energy and Exergy Analysis of Desalination Processes}

\subsection{First Law of Thermodynamics}

The first law of thermodynamics has been commonly used to analyze desalination technologies which considers, primarily, the quantity of energy utilized in a process. A general representation of a phase-change desalination process, including an evaporator and a condenser, is shown in Figure 1 [20]. Based on first law of thermodynamics, the energy balance on the low temperature desalination unit can be written as follows:

Energy efficiency of the desalination system is given as:

$$
T h_{e f f}=\frac{m_{f \times h_{v}}}{Q_{i}}
$$

This Equation is also called gained output ratio (GOR) which is less than 1 for a solar powered single stage desalination system.

\subsection{Exergy of Energy Flows}

Different forms of energy flows are utilized in desalination processes which include kinetic, potential, heat, mechanical, electrical, chemical, and radiation energies, as shown in Figure 2 [21]. There are two forms of exergy: physical (mechanical and thermomechanical) and chemical (reactions and separations). Thermal desalination processes account for the heat and mass balances thus involving all forms of exergy in a flow. Membrane processes do not necessarily account for exergy related to heat in the process.

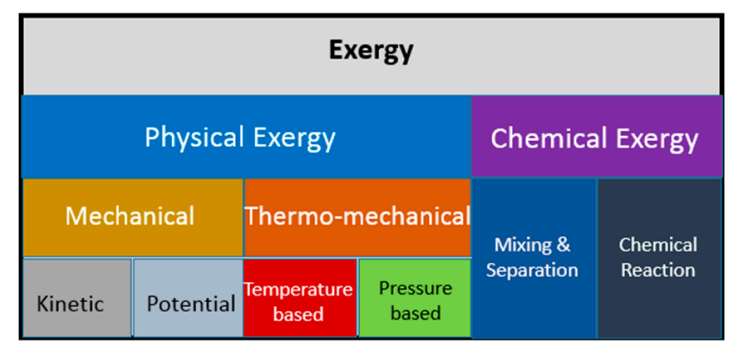

Figure 2. Exergy flows in a process stream, after [21].

Other forms of energy that could be of interest in solar desalination is through radiation. Electrical energy is common to both thermal and membrane processes. Specific exergy contents (expressions) for these flows are shown in Table 1 (where $V$ is velocity of the flow, $g$ is acceleration due to gravity, $T$ is the temperature of the flow, $T_{\mathrm{o}}$ is the temperature of the reference environment, $\mathrm{w}$ includes the volume and pressure difference in the flow, $g_{\mathrm{G}}$ is the chemical exergy, $\mu$ is the chemical exergy depending on the concentration of the flow, $R$ is the universal gas constant, $V$ is the voltage applied, and $I$ is the solar irradiation) [22]. Chemical exergy depends on the composition of the solvents and significantly influences the exergy performance of a flow system [23].

Table 1. Specific exergy expressions for different flows.

\begin{tabular}{ccc}
\hline Type of Energy Flow & Specific Energy & Specific Exergy \\
\hline Kinetic & $0.5 V^{2}$ & $0.5 V^{2}$ \\
Potential & $g \Delta z$ & $g \Delta z$ \\
Heat & $q$ & $q\left\{1-\frac{T_{0}}{T_{q}}\right\}$ \\
Mechanical & $w$ & $w$ \\
Electrical & $I t \Delta V$ & $I t \Delta V$ \\
Chemical, pure substance & $\Delta g_{\mathrm{G}}$ & $\mu-\mu_{0}+R T_{0} \ln \left(c / c_{0}\right)$ \\
Radiation & $I$ & $\sigma\left[1+\frac{1}{3}\left(\frac{T_{o}}{T_{s}}\right)^{4}-\frac{4}{3}\left(\frac{T_{o}}{T_{s}}\right)\right]$ \\
\hline
\end{tabular}




\subsection{Exergy Analysis}

A complete steady-state analysis of energy conversion/utilization processes can be made based on mass, energy, and exergy balances. Ignoring kinetic and potential energy terms, the three balances for a control volume are [22,24]:

Mass balance:

$$
0=\sum_{i} \dot{m}_{i}-\sum_{e} \dot{m}_{e}
$$

Energy balance:

$$
0=\dot{Q}-\dot{W}+\sum_{i}(\dot{m} \cdot h)_{i}-\sum_{e}(\dot{m} \cdot h)_{e}
$$

Exergy balance:

$$
0=\sum_{j}\left[1-\frac{T_{0}}{T_{j}}\right] \dot{Q}_{j}-\dot{W}+\sum_{i}(\dot{m} \cdot e)_{i}-\sum_{e}(\dot{m} \cdot e)_{e}-\dot{E}_{D}
$$

The variables are defined in the Nomenclature.

While the mass and energy balance equations are well known, only the exergy balance is detailed here. The terms on the right hand side of the exergy Equation represent the exergy associated with heat transfer, $j$ at temperature $T_{j}$; the work transfer; the exergy inflow; the exergy outflow; and the exergy destruction, respectively. The exergy inflow and outflow associated with the streams entering and leaving the control volume are quantified in terms of the specific exergy, $e$, defined as follows:

$$
e=\left(h-h_{0}\right)-T_{o}\left(s-s_{0}\right)
$$

In the case of ideal gases, the following Equation can be expressed in terms of temperatures and pressures:

$$
e x=c_{p} T_{o}\left[\frac{T}{T_{o}}-1-\ln \left(\frac{T}{T_{o}}\right)\right]+\ln \left(\frac{p}{p_{o}}\right)^{(k-1) / k}
$$

For a given set of operating conditions and the corresponding properties of the working fluid, the rates of exergy destruction and exergy loss for each component of the process can be computed from the above equations.

The following measures can now be defined to assess the thermodynamic performance of the components of a system and the entire system $[9,24]$ :

Exergy destruction ratio for component $c$ of the system, $y_{D, c}$ :

$$
y_{D, c}=\frac{\text { Exergy destruction in component, } \dot{E}_{D, c}}{\text { Exergy destruction in system, } \dot{E}_{D}}
$$

Exergy destruction ratio for complete system, $y_{D}$ :

$$
y_{D}=\frac{\text { Exergy destruction in system, } \dot{E}_{D}}{\text { Exergy of fuel supplied, } \dot{E}_{F}}
$$

Exergy loss ratio for the complete system $y_{L}$ :

$$
y_{L}=\frac{\text { Exergy loss in system, } \dot{E}_{L}}{\text { Exergy of fuel supplied, } \dot{E}_{F}}
$$


Exergetic efficiency, $\psi$ :

$$
\psi=1-\left(\frac{\dot{E}_{D}+\dot{E}_{L}}{\dot{E}_{F}}\right)
$$

Exergy efficiency of the desalination system shown in Figure 2 can be defined in two forms as shown below.

Exergy efficiency based on the latent heat (available energy or exergy) in the water vapor (steam) generated from EC:

$$
E x_{e f f}=\frac{m_{f} h_{v}\left(1-\frac{T_{o}}{T}\right)}{Q_{i n}}
$$

Overall exergy efficiency based on available energy or exergy in the freshwater condensed in condenser (final product):

$$
E x_{e f f}=\frac{m_{f}\left\{\left(h_{f}-h_{o}\right)-T_{o}\left(s_{f}-s_{o}\right)\right\}}{Q_{i n}}
$$

This Equation is based on the available energy (exergy) in the water vapor generated from EC. The reference temperature was chosen as $298 \mathrm{~K}$. Here, $h$ and $s$ are enthalpy and entropy of the corresponding fluid.

When the heat source is provided by solar energy, the Petela expression can be used to calculate the exergy of solar radiation [25]:

$$
\dot{E}_{s}=A I_{S}\left[1+\frac{1}{3}\left(\frac{T_{0}}{T_{s}}\right)^{4}-\frac{4}{3}\left(\frac{T_{0}}{T_{S}}\right)\right]
$$

where $\dot{E}_{s}$ is the solar exergy flow, $A$ is the area of the collector, $I_{s}$ is the solar insolation (variables are defined in Nomenclature).

\subsection{Why Exergy Analysis in Desalination Processes}

Actual desalination process energy costs are 5-10 times higher than the ideal process energy costs, indicating a second law efficiency of under $20 \%$. This also means that desalination plant performance, especially, MSF and RO plants, can be improved significantly [24,26,27]. The key to improving the process performance is by diagnosing the process components using second law analysis. Process diagnostics using thermodynamic principles will identify the units responsible for highest entropy generation, i.e., exergy destruction. The level of exergy destruction in desalination processes varies

\begin{tabular}{|c|c|c|c|}
\hline \multirow{2}{*}{ Process } & \multicolumn{2}{|c|}{ Exergy Destruction } & \multirow{2}{*}{ Basis for Calculation } \\
\hline & kWh/ton & $\mathrm{J} / \mathrm{mol}$ & \\
\hline Reverse osmosis & 0.98 & 63.8 & $35 \mathrm{~atm}$ excess pressure at $25^{\circ} \mathrm{C}$ \\
\hline Electrodialysis & 12.87 & 834 & 0.8 Voltage per membrane pair at $25^{\circ} \mathrm{C}$ \\
\hline Vapor compression & 2.77 & 179 & Compression unit temp. $60.75^{\circ} \mathrm{C} ; \Delta T=1.5^{\circ} \mathrm{C}$ \\
\hline Multi-effect evaporation & 2.83 & 183 & Average temperature of $50.75^{\circ} \mathrm{C} ; \Delta T=1.5^{\circ} \mathrm{C}$ \\
\hline Multi-stage flash desalination & 4.89 & 316.5 & Average temperature of $71.5^{\circ} \mathrm{C} ; \Delta T=3{ }^{\circ} \mathrm{C}$ \\
\hline
\end{tabular}
from process to process which are shown in Table 2 [28]. Basis for exergy calculations are provided in the table, for more details refer to [28].

Table 2. Exergy destruction in a desalination process [28].

Exergy destruction in a desalination process depends on the process and operational parameters related to feed water, heat source, process type, withdrawal and discharge conditions, and system configuration, such as hybrid or combine power and water production. Therefore, it is rather difficult to discuss the exergy variations in detail and provide examples for each case. This article presents summaries of a few studies which focused on the exergy performance of the major desalination processes. 
Details related to the process are not provided but exergy destruction in the process are discussed. Readers are encouraged to refer to the original reports discussed in this paper for more details.

\section{Case Studies for Desalination Exergy Performance Analysis}

\subsection{MSF Desalination}

Kahraman and Cengel [29] evaluated the thermodynamic performance of a large-scale MSF desalination plant using actual plant data and operational data. Exergy flow rates were evaluated throughout the plant to determine the locations of major exergy destruction. The MSF unit contributed the majority of exergy destruction, which has the following operational data: water production capacity of $8.7 \times 10^{5} \mathrm{~m}^{3} /$ day with an integrated power production capacity of $1295 \mathrm{MW}$ with 40 MSF units each consisting of 22 flashing stages. Each MSF unit has a capacity of $23,500 \mathrm{~m}^{3} /$ day. Seawater (a flow of $2397 \mathrm{~kg} / \mathrm{s}$ ) at $35^{\circ} \mathrm{C}$ and a salinity of $46,500 \mathrm{ppm}$ enters the desalination plant. A major portion of the incoming seawater is used as the cooling water and rejected into the sea while the rest $(808 \mathrm{~kg} / \mathrm{s})$ is supplied through the MSF stages. The saline water is then flashed through the MSF stages at lower pressures in each stage successively with a total pressure drop of $627 \mathrm{kPa}$. The saline water (brine) is discharged at a flow rate of $536 \mathrm{~kg} / \mathrm{s}$ and a salinity of about 70,000 ppm.

The results from the exergy analysis are shown in Figure 3. The total second law efficiency was determined to be $4.2 \%$. Majority of the exergy destruction occurred in the MSF distillation units. About $78 \%$ of the exergy destruction was calculated for MSF distillation unit, followed by $8.3 \%$ of exergy destruction in the heat exchangers, pumps and motors with a contribution of $5.3 \%$ and the discharge of cooling water having an exergy destruction of $4.8 \%$. The remaining $3.8 \%$ of the exergy destruction occurred in throttling valves and discharge of the brine and product waters.

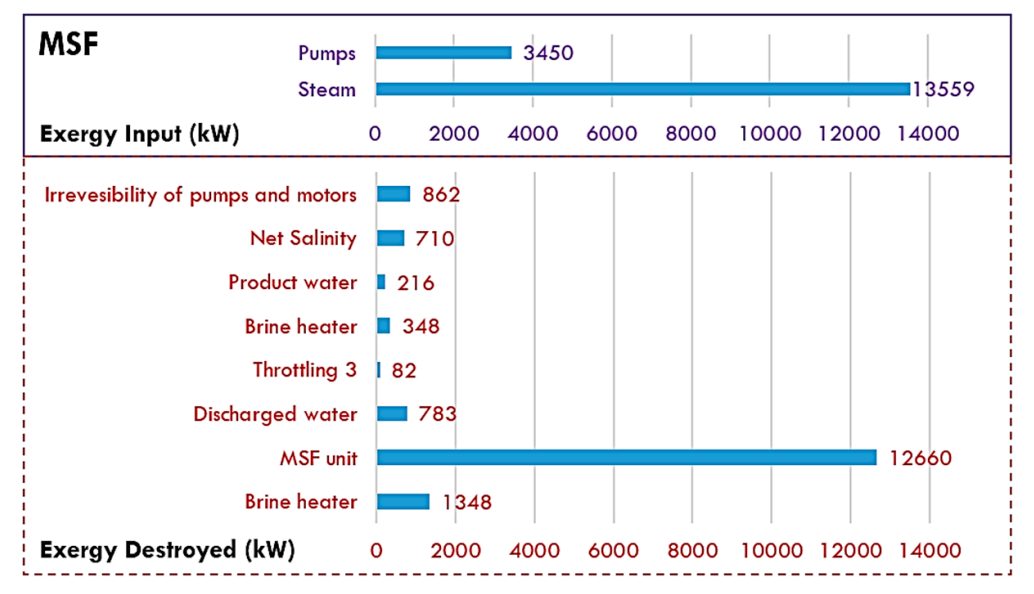

Figure 3. Exergy balance of the Al-jubail MSF plant (data taken from [29]).

The exergy efficiency of this MSF plant is similar to the others but it is quite low when compared with a modern power plant which has an efficiency of up to 50\% [30]. The exergy destruction in the MSF plants suggests the potential for improvements in its thermodynamic performance. To improve the exergy efficiency of the MSF distillation units, the number of stages could be increased, but at a higher capital cost, which may not be desirable. The other major exergy input is through the electrical energy supplied to the pumps which is a prime quality energy. This portion of exergy destruction can be reduced by utilizing high efficiency pumps and motors. Use of high quality steam in the plant is another contributor for the exergy losses, indicating possible use of low quality and low temperature steam. Standalone MSF units cannot be thermodynamically efficient for the above reasons. Therefore, consideration of cogeneration with power plants will provide higher benefits since the high quality steam produced by power plants can be used by the MSF unit which itself would serve as a condenser for the power plant [29]. 
Another study was performed on an MSF desalination plant with a water production capacity of $32,880 \mathrm{~m}^{3}$ / day and a top brine temperature of $110^{\circ} \mathrm{C}$. The seawater enters at temperature of $27^{\circ} \mathrm{C}$ and a flow rate of $1370 \mathrm{~m}^{3} / \mathrm{h}$ [31]. Heating steam is supplied at $205^{\circ} \mathrm{C}$ at a pressure of 7 bar. This plant had a gain output ratio of 7.91. The exergy input into the MSF unit in the form of heating steam and pumping power was 10.7 MW (Figure 4). The exergy of the cooling water was 4.04 MW. Similar to the previous study, the MSF unit was the major contributor for exergy destruction with up to $6.5 \mathrm{MW}$. The total exergetic efficiency of this plant was 1.9\% [31]. The lower exergy efficiency of this plant can be realized in the higher steam temperatures and higher top brine temperatures. Higher exergy losses occurred through brine discharges in this system. High steam temperatures mean higher exergy supply, therefore low temperature steam could be used to increase exergy efficiency.

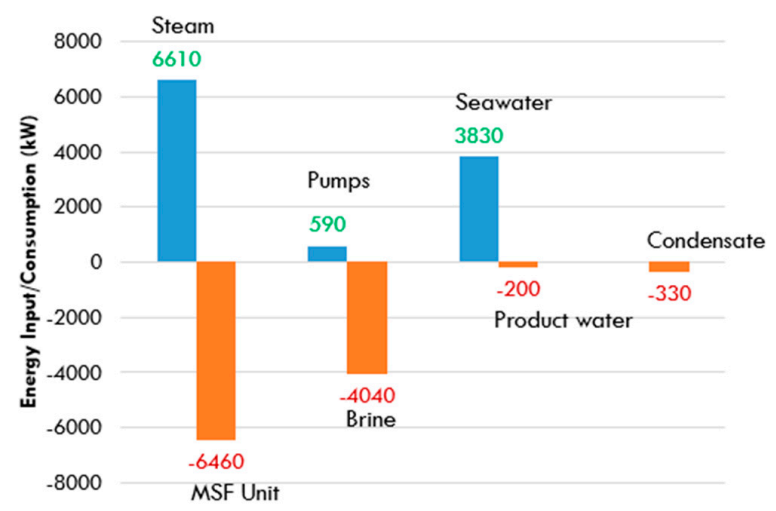

Figure 4. Exergy input and destruction in an MSF plant.

Table 3 presents a summary of various approaches for achieving maximum exergy efficiency in the MSF process. Developing hybrid configurations, recirculation of brine streams, and reuse of waste heat may help achieve optimal exergy performance in the MSF process.

Table 3. Exergy performance in MSF processes.

\begin{tabular}{|c|c|c|c|}
\hline Process & Description & Performance & Ref. \\
\hline \multirow{2}{*}{$\begin{array}{l}\text { Solid oxide fuel cell-gas } \\
\text { turbine (SOFC-GT) hybrid } \\
\text { system integrated with a } \\
\text { multi stage flash (MSF) } \\
\text { desalination unit. }\end{array}$} & $\begin{array}{l}\text { Heuristic optimization method, } \\
\text { namely, multi-objective genetic } \\
\text { algorithm (MOGA). }\end{array}$ & $\begin{array}{l}\text { Maximum achievable exergy efficiency } \\
\text { of } 46.7 \% \text { with optimal design. }\end{array}$ & \multirow{2}{*}{ [32] } \\
\hline & $\begin{array}{l}\text { Desalination } \\
\text { capacity-256 } \mathrm{m}^{3} / \text { day; } \\
\text { performance ratio of } 8.8\end{array}$ & MSF system exergy efficiency-3.49\% & \\
\hline $\begin{array}{l}\text { MSF with heat recovery from } \\
\text { hot distillate water stages }\end{array}$ & $\begin{array}{l}\text { IPSEpro software was used. } \\
\text { Capacity-91,200 } \mathrm{m}^{3} / \text { day; } \# \text { of } \\
\text { stages } 19 \text { (16 heat recovery + } \\
3 \text { heat rejection) with a } \\
\text { performance ratio of } 8.43\end{array}$ & $\begin{array}{l}\text { Overall exergy efficiency-5.8\% } \\
\text { Exergy destroyed: } \\
\text { heat recovery stages-55.0\% } \\
\text { brine heater-17.0\% } \\
\text { heat rejection stages-10.0\% } \\
\text { pumps-4.3\% } \\
\text { brine streams disposal-14.0\% } \\
\text { With heat recovery- }-14.0 \%\end{array}$ & [33] \\
\hline \multirow{4}{*}{$\begin{array}{l}\text { Recirculating MSF plants in } \\
\text { Saudi Arabia, namely, } \\
\text { Al-Khobar II, Al-Jubail II, } \\
\text { and Shuaibah }\end{array}$} & $\begin{array}{l}\text { Quantitative assessment of MSF } \\
\text { desalination plants. }\end{array}$ & TBT_Exergy efficiency & \multirow{4}{*}{ [34] } \\
\hline & $\begin{array}{l}\text { Al-Khobar II: } \\
\text { Capacity-194,200 } \mathrm{m}^{3} / \text { day; \# of } \\
\text { stages-16 (10 identical units) }\end{array}$ & $\begin{array}{l}87^{\circ} \mathrm{C}-4.61 \% \\
106^{\circ} \mathrm{C}-5.21 \% \\
115^{\circ} \mathrm{C}-5.35 \% \\
\end{array}$ & \\
\hline & $\begin{array}{l}\text { Al-Jubail II: } \\
\text { Capacity-940,000 } \mathrm{m}^{3} / \text { day; \# of } \\
\text { stages-22 (40 identical units) }\end{array}$ & $\begin{array}{l}90.6^{\circ} \mathrm{C}-10.02 \% \\
90.8^{\circ} \mathrm{C}-10.38 \% \\
112.8^{\circ} \mathrm{C}-7.61 \%\end{array}$ & \\
\hline & $\begin{array}{l}\text { Shuaibah: } \\
\text { Capacity-181,818 } \mathrm{m}^{3} / \text { day; \# of } \\
\text { stages-19 (10 identical units) }\end{array}$ & $\begin{array}{l}76.5^{\circ} \mathrm{C}-3.57 \% \\
90.0^{\circ} \mathrm{C}-1.78 \% \\
101.5^{\circ} \mathrm{C}-1.12 \%\end{array}$ & \\
\hline
\end{tabular}




\subsection{Multi-Effect Distillation (MED) or Evaporation (MEE) Process}

\subsubsection{Exergy Evaluation of MED Process}

Thermal desalination processes offer numerous opportunities for improving energy efficiency. This is mainly due to the cascaded operation of evaporation and condensation cycles which allow for recycling and reutilization of latent heat in several stages. Similar to the MSF process, the MED process also operates in multi-stage operation. Very few studies focusing on exergy evaluation of the MED process are reported thus far [35,36]. A computer program was developed to analyze the exergy performance of a solar powered MED desalination system [35]. This study reported that inclusion of energy recovery systems may increase the exergy efficiency of the desalination process from $14.3 \%$ to $25.7 \%$. In another study, a $15,000 \mathrm{~m}^{3}$ / day capacity MED desalination plant was evaluated exergetically [36]. Here, the number of effects in the desalination process is shown to have a major impact on the exergy efficiency of the desalination process. An increase in the number of effects, i.e., from 1 effect to 6 effects increased the exergy efficiency from $3.8 \%$ to $8.4 \%$. The MED process operates at a much lower temperature range compared to an MSF process. This limits the temperature differential (between the top brine temperature (TBT) in the first effect and lower brine temperature (LBT) in the last effect) available for the number of stages which allows for energy and product recovery [37]. For this reason, thermal processes (MSF and MED) are often integrated with a low temperature or waste heat driven adsorption cycle to increase the difference between the TBT and LBT from $70-40{ }^{\circ} \mathrm{C}$ to $70-10{ }^{\circ} \mathrm{C}$, thereby increasing the potential number of MED or MSF evaporation stages/effects from a conventional range of 15 to 60 stages with the temperature drop per stage varying from 2 to $2.5 \mathrm{~K}$. As a result, the specific energy consumption of the thermal desalination processes reduces drastically from $32 \mathrm{kWh}$ th $/ \mathrm{m}^{3}$ to $11 \mathrm{kWh}$ th $/ \mathrm{m}^{3}$.

\subsubsection{MED-TVC Process}

MED-TVC (thermal vapor compression) combination is one of the most commonly reported configurations in the desalination processes. This combination is motivated by the following benefits: operational flexibility; fewer moving parts; less corrosion risk due to lower operating temperature range; and higher thermodynamic efficiency [38]. In principle, the TVC unit reutilizes the energy exerted from the last of the MED unit through a thermos-compressor (steam ejector) to reduce the heat loss in the final condenser and supply the energy required in the first effect of MED [39]. Exergy evaluation of MED-TVC systems are more common than the single MED process. The first exergy analysis of an MED-TVC system was reported in 1996 on a four-stage plant operating at a performance ratio of 6.5, located in the United Arab Emirates [39,40]. The exergy evaluation study reported that major exergy destruction occurred in the first-stage of the MED unit and in the thermos-compressor of the TVC unit [40]. These results later confirmed by another study which suggested that the exergy inefficiency was due to high fuel exergy [41]. A study comparing three different configurations of MED-TVC systems further emphasized that the thermos-compressor and evaporator stages were the units contributing the most to the exergy losses [42]. The first effect contributed up to $50 \%$ of the total exergy destruction. Another analysis on $4500 \mathrm{~m}^{3} /$ day, $10,000 \mathrm{~m}^{3} /$ day, $16,000 \mathrm{~m}^{3} /$ day, and $20,000 \mathrm{~m}^{3} /$ day plant capacities reported that $70 \%$ of the total exergy destruction occurred in the TVC stage [43]. A detailed first and second law analysis of the MED-TVC process showed that the process is insensitive to concentration factor, rather a higher value of compression ratio should be maintained in the compressor for reduction of exergy destruction [44]. Analysis by Esfahani et al. [45] and Eshoul et al. [46] confirmed that a higher number of effects in the MED process may result in higher gained output ratio and lower product exergy costs. Attributing to irreversibilities in thermo-compressor and evaporators, a study on a 4-stage $46,000 \mathrm{~m}^{3}$ /day capacity plant reported an exergy efficiency of $3.95 \%$ [45]. Using specialized software, a comprehensive study on a $24,000 \mathrm{~m}^{3} /$ day capacity plant has shown that $40 \%$ and $35 \%$ exergy destruction have occurred in thermos-compressor and MED evaporator effects, respectively [46]. Another study focusing on optimization of a pilot 
MED plant process parameters based on energy and exergy performance criteria has revealed that high thermal energy consumption (i.e., utilization) is due to the discharged mass outflows while entropy generation and the environmental losses are the causes for exergy destruction [47]. It was also shown that not all operational parameters have an influence on the performance of the desalination plant. Piacentino [48] studied an 8-effect forward feed MED plant's thermodynamic performance and thermoeconomics using models developed in engineering equation solver. The combined study analysis has shown that the exergy (physical and chemical) costs vary throughout the plant significantly. An important observation was that the exergy costs of the freshwater in the last effects of the MED process are higher than the freshwater from earlier effects.

Table 4 presents details on the exergy performances of MED-M/TVC processes and combined water-power generation systems using these desalination processes.

Table 4. Exergy performance in MED and Hybrid processes.

\begin{tabular}{|c|c|c|c|}
\hline Process & Description & Performance & Ref. \\
\hline \multirow{3}{*}{ MEE-MVC } & $\begin{array}{l}\text { Capacity }-5000 \mathrm{~m}^{3} / \text { day; feed temperature }-27^{\circ} \mathrm{C} \text {; } \\
\text { compressor }-60{ }^{\circ} \mathrm{C} \text {; heating steam }-70^{\circ} \mathrm{C} \\
\text { \# of evaporators }-1-6\end{array}$ & $\begin{array}{l}\text { Exergy efficiency: } \\
1 \text { effect }(3.8 \%) ; \\
2 \text { effects }(5.8 \%) ; \\
3 \text { effects }(6.6 \%) ; \\
4 \text { effects }(7.5 \%) ; \\
6 \text { effects (no change) }\end{array}$ & \multirow{3}{*}{ [49] } \\
\hline & $\begin{array}{l}\text { Capacity }-1500 \mathrm{~m}^{3} / \text { day; feed temperature }-27^{\circ} \mathrm{C} \text {; } \\
\text { compressor- } 60^{\circ} \mathrm{C} \text {; heating steam }-70^{\circ} \mathrm{C} \\
\text { \# of evaporators }-1-6\end{array}$ & $\begin{array}{l}\text { Exergy efficiency: } \\
1 \text { effect }(3.8 \%) ; \\
2 \text { effects }(5.8 \%) ; \\
3 \text { effects }(6.6 \%) ; \\
4 \text { effects }(7.5 \%) ; \\
6 \text { effects }(8.4 \%) ; \\
8 \text { effects (no change) }\end{array}$ & \\
\hline & $\begin{array}{l}\text { Capacity }-3750 \mathrm{~m}^{3} / \text { day; feed temperature }-21^{\circ} \mathrm{C} \text {; } \\
\text { Evaporator } 1-65{ }^{\circ} \mathrm{C} \text {; Evaporator } 2-60{ }^{\circ} \mathrm{C} \\
\text { Evaporator surface area-2670 } \mathrm{m}^{2}\end{array}$ & $\begin{array}{l}\text { Exergy efficiency } \\
\text { With make-up steam-4.34\% } \\
\text { Without make-up steam-5.75\% }\end{array}$ & \\
\hline \multirow{2}{*}{ MEE-TVC } & $\begin{array}{l}\text { Capacity }-1200 \mathrm{~m}^{3} / \text { day; feed temperature and } \\
\text { TDS }-27{ }^{\circ} \mathrm{C} \text { and } 45,000 \mathrm{mg} / \mathrm{L} \text {; \# of evaporators and } \\
\text { surface area-2 and } 2160 \mathrm{~m}^{2}\end{array}$ & Exergy efficiency-2.2\% & \multirow{4}{*}{ [50] } \\
\hline & $\begin{array}{l}\text { Capacity }-5000 \mathrm{~m}^{3} / \text { day; feed temperature and } \\
\text { TDS }-27{ }^{\circ} \mathrm{C} \text { and } 45,000 \mathrm{mg} / \mathrm{L} \text {; } \# \text { of evaporators and } \\
\text { surface area-2 and } 8978 \mathrm{~m}^{2}\end{array}$ & Exergy efficiency-2.1\% & \\
\hline \multirow{2}{*}{ MEE-MVC } & $\begin{array}{l}\text { Capacity }-1500 \mathrm{~m}^{3} / \text { day; feed temperature and } \\
\text { TDS }-27{ }^{\circ} \mathrm{C} \text { and } 45,000 \mathrm{mg} / \mathrm{L} \text {; \# of evaporators and } \\
\text { surface area-2 and } 3866 \mathrm{~m}^{2}\end{array}$ & Exergy efficiency-5.8\% & \\
\hline & $\begin{array}{l}\text { Capacity }-5000 \mathrm{~m}^{3} / \text { day; feed temperature and } \\
\text { TDS }-27{ }^{\circ} \mathrm{C} \text { and } 45,000 \mathrm{mg} / \mathrm{L} \text {; \# of evaporators and } \\
\text { surface area-2 and } 12848 \mathrm{~m}^{2}\end{array}$ & Exergy efficiency-5.8\% & \\
\hline MED-TVC & $\begin{array}{l}\text { Capacity- } 5000 \mathrm{~m}^{3} / \text { day; forward feed type, } 12 \text { effects } \\
\text { combined with TVC at the last effect. Exergy } \\
\text { efficiency at different steam extraction pressures: } P a= \\
4890 \mathrm{kPa}, P b=2800 \mathrm{kPa}, P c=1480 \mathrm{kPa}, P d=700 \mathrm{kPa} \\
\text { and } P e=290 \mathrm{kPa}\end{array}$ & $\begin{array}{l}\text { Exergy efficiencies: } \\
\quad P a-4.9 \% \\
P b-5.0 \% \\
P c-5.1 \% \\
P d-6.0 \% \\
P e-7.1 \%\end{array}$ & \multirow{2}{*}{ [51] } \\
\hline $\begin{array}{l}\text { Combined } \\
\text { CHP-MED-TVC }\end{array}$ & $\begin{array}{l}\text { Capacity- } 5000 \mathrm{~m}^{3} / \text { day; forward feed type, } 12 \text { effects } \\
\text { combined with TVC at the last effect; } \# \text { of MED units: } \\
0-4 . \text { Exergy efficiency at different steam extraction } \\
\text { pressures: } P a=4890 \mathrm{kPa}, P b=2800 \mathrm{kPa}, P c= \\
1480 \mathrm{kPa}, P d=700 \mathrm{kPa} \text { and } P e=290 \mathrm{kPa}\end{array}$ & $\begin{array}{l}\text { Exergy efficiencies: } \\
\qquad a(4-0)-2.5-3.8 \% \\
P b(4-0)-2.6-3.8 \% \\
P c(4-0)-2.8-3.8 \% \\
P d(4-0)-2.9-3.8 \% \\
P e(4-0)-3.0-3.8 \%\end{array}$ & \\
\hline $\begin{array}{l}\text { Gas Turbine + } \\
\text { MED + RO }\end{array}$ & $\begin{array}{l}\text { Capacity-16874 } \mathrm{m}^{3} / \text { day; Power } \\
\text { production-10 MW. Power-water generation unit } \\
\text { consisting of compressor, gas turbine (GT), } \\
\text { combustion chamber (CC), Air compressor (AC), high } \\
\text { recovery steam generation (HRSG), MED and RO }\end{array}$ & $\begin{array}{l}\text { Exergy Destruction: } \\
\text { AC- } 2.0 \% \\
\text { CC }-14.0 \% \\
\text { GT- } 1.5 \% \\
\text { HRSG-5.9\% } \\
\text { MED-3.9\% } \\
\text { RO- } 0.5 \%\end{array}$ & [52] \\
\hline
\end{tabular}




\subsection{Reverse Osmosis Membrane Process}

A reverse osmosis desalination plant with a treatment capacity of $7250 \mathrm{~m}^{3} /$ day was evaluated for its exergy performance [53]. The plant received a brackish water source with a salinity of 1550 ppm and the product water had a salinity of less than $500 \mathrm{ppm}$. The flow schematic of the reverse osmosis plant is shown in Figure 5.

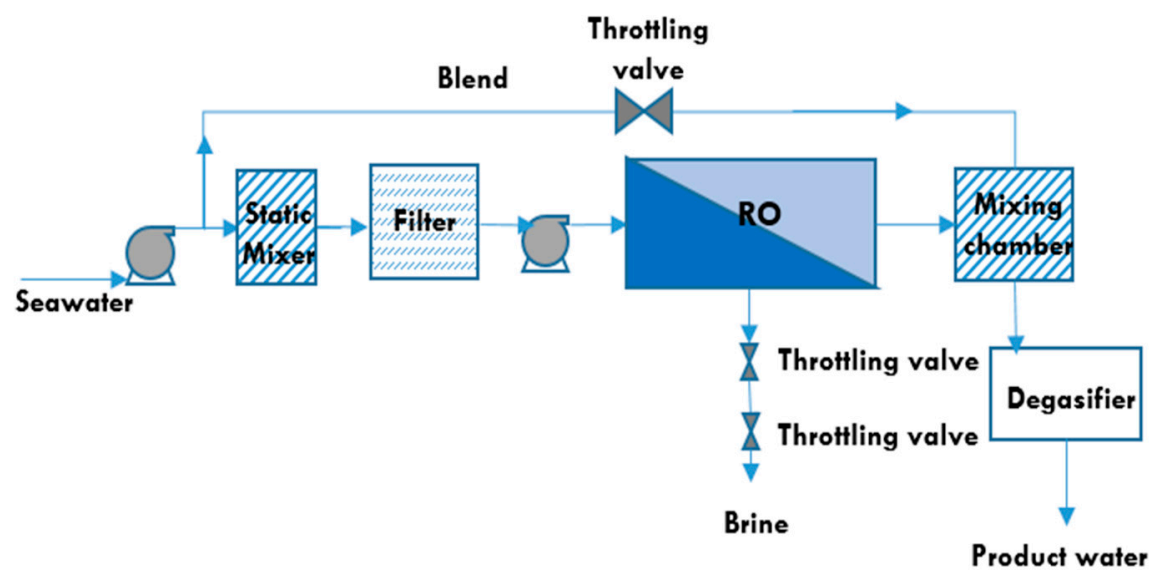

Figure 5. Flow schematic of a reverse osmosis unit receiving brackish water.

The brackish water is supplied by a low pressure pump from which a partial flow is bypassed as blend. The raw water passes through static mixer to add chemicals to prevent potential scaling and fouling and then it passes through filters to remove the contaminants and suspended solids before it is pumped (high pressure pumps) through the reverse osmosis unit. The permeate flow from the RO unit will then be blended with the bypass saline water to produce product water with a required salinity of less than 500 ppm. The exergy analysis of the unit is shown in Figure 6. The RO membrane unit accounts for the maximum exergy destruction in this unit which accounts for up to 74.1\% [53]. Throttling valves contribute to other significant exergy losses and the smallest exergy losses occur in the static mixer and filter. The second law efficiency of the plant was $4.3 \%$. The exergy efficiency was improved to $4.9 \%$ with addition of a pressure exchanger which resulted in savings of $19.8 \mathrm{~kW}$.

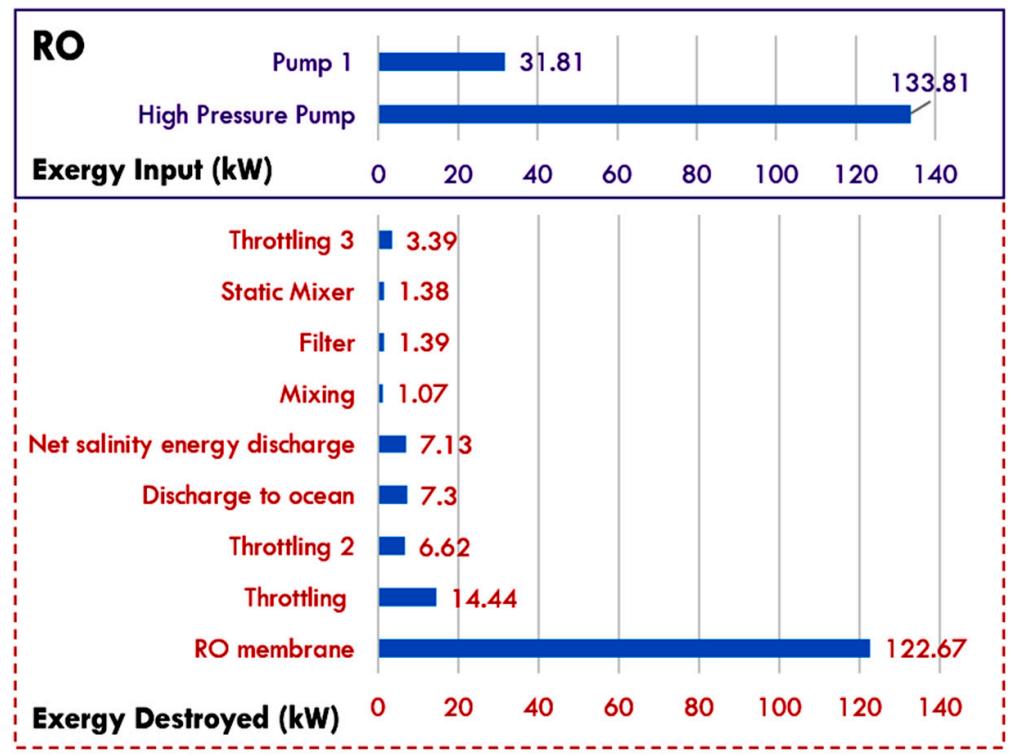

Figure 6. Exergy balance of a reverse osmosis unit receiving brackish water. 
Another study reported the exergy analysis of a desalination plant in Jordan which received brackish water feedwater with a salinity of $2500 \mathrm{ppm}$ [54]. This unit had two RO units which produced permeates of 90 and $70 \mathrm{ppm}$ respectively. Similar to the flow scheme in Figure 5, this unit had pressure filters and cartridge filters followed by $\mathrm{RO}$ units, a decarbonator, and a hydrostatic water tank. The exergy performance of the RO unit is shown in Figure 7. The majority of exergy destruction occurred in the throttling valves which accounted up to $56.8 \%$ followed by membrane units with $21 \%$ of total exergy destruction. The pumps and motors caused 19.6\% exergy destruction. The second law efficiency of this plant was $4.1 \%$ which was similar to the previous study reported by Cerci [53]. This analysis showed that the filters had higher exergy efficiencies. This analysis also suggested that replacement of throttling valves with energy recovery devices and pumps equipped with variable frequency motors might reduce the exergy destruction in the overall $\mathrm{RO}$ unit.

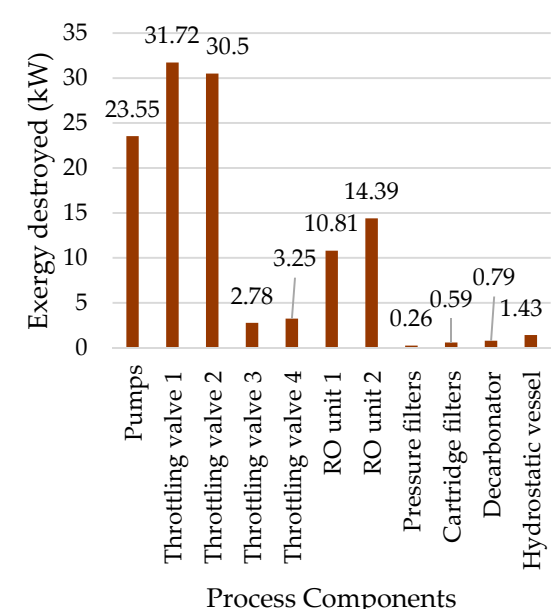

Process Components
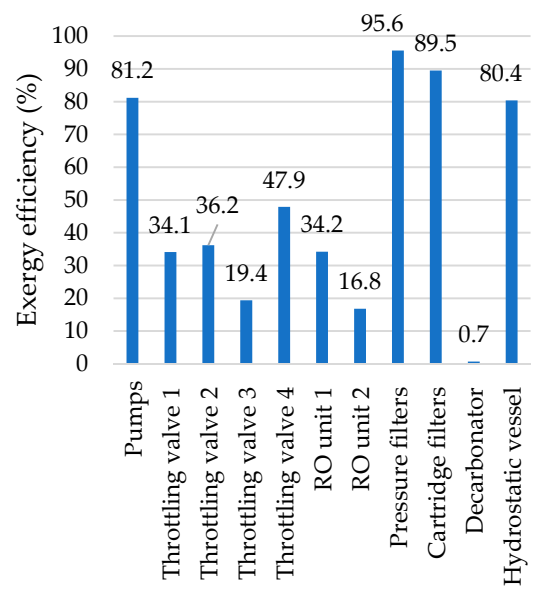

Process Components

(a)

(b)

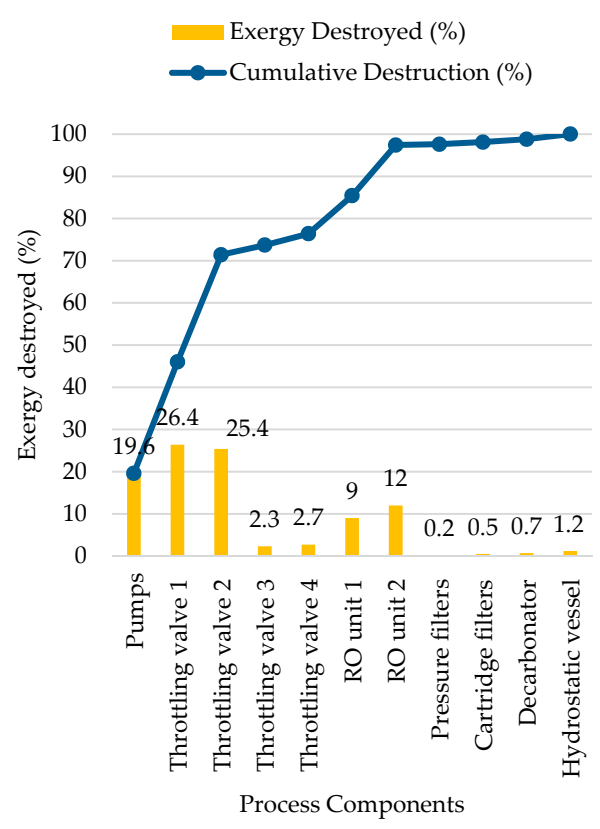

(c)

Figure 7. Exergy balance of a reverse osmosis unit receiving brackish water: (a) exergy destroyed (kW); (b) exergy efficiency (\%), and (c) exergy destroyed (\%). 
In reverse osmosis systems, energy recovery can be accomplished through energy recovery devices which are known as turbine systems or pressure exchanger systems. Turbine systems consist of Pelton wheel or turbo-charger systems which convert the potential energy from the brine into mechanical energy. This energy can be supplied to the feed pump as an auxiliary power supply or directly to the feed water to reduce the specific energy use in the system. The pressure exchanger systems are also known as work exchangers which directly transfer the pressure from the brine to the feed water. Pressure exchangers are able to recover up to $98 \%$ of the pressure energy in the brine which is the highest energy recovery efficiency available in the industry. The Pelton turbines and turbochargers have longer history than the pressure exchangers but only have energy recovery efficiencies of $90 \%$. With energy recovery devices, the specific energy requirements for desalination were reduced significantly which are between 2 and $4 \mathrm{kWh} / \mathrm{m}^{3}$ for seawater and less than $1 \mathrm{kWh} / \mathrm{m}^{3}$ for brackish waters.

The energy recovery process also involves exergy destruction. A seawater reverse osmosis (SWRO) desalination plant with an energy recovery device (Pelton Turbine) achieved about $48.5 \%$ exergy efficiency [55]. This plant was located in Santa Cruz de Tenerife metropolitan area (Canary Islands, Las Palmas, Spain). The feed water (seawater) had a concentration of 36,888 ppm with a product recovery of $42 \%$. The capacity of the desalination plant was $21,000 \mathrm{~m}^{3} /$ day. The high pressure pump required an energy flow of $4 \mathrm{MW}$, of which $40 \%$ was recovered by the Pelton turbine. The exergy destruction $(\mathrm{kW})$ and losses (\%) are shown in Figure 8. The total exergy destruction in the SWRO plant was $2050 \mathrm{~kW}$. The RO membrane modules were responsible for $34.4 \%(704 \mathrm{~kW})$ of exergy destruction. The Pelton turbine contributed the next highest exergy destruction of $23.7 \%$ followed by high pressure pump and product distribution. All of these core processes have contributed to more than $80 \%$ of exergy losses [55].

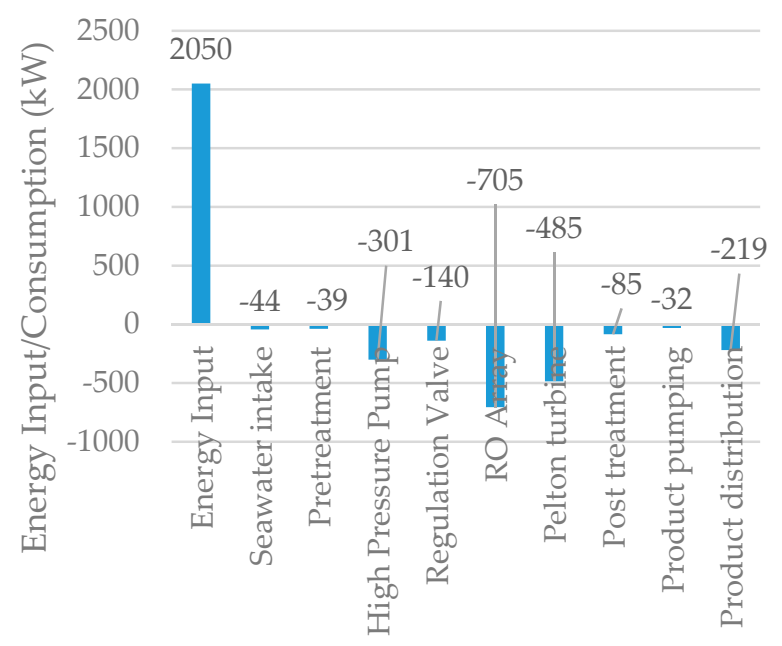

Figure 8. Exergy balance of a seawater reverse osmosis unit with an energy recovery device.

\subsection{Integrated Membrane Systems}

Membrane filtration processes such as ultrafiltration or microfiltration and nanofiltration can be used as a pre-treatment method for reverse osmosis process [56]. Because reverse osmosis membranes are susceptible to scaling and biofouling, a high level of pretreatment is often necessary to maintain the water quality as well as the longevity of membranes. Three different systems are shown in Figure 9. A simple system of direct RO system (System 1); an RO system with a nanofiltration as a pretreatment step (System 2), and an RO system with a microfiltration and nanofiltration unit as pretreatment steps (System 3). System 1 operates on direct seawater as feed while System 2 operates on nanofiltration permeate as feed. In System 3, the RO unit operates on the permeate that passed through both micro and nanofiltration units. Table 5 shows the seawater flow rates and concentrations and the 
freshwater recovery efficiencies for the three systems. Three case studies were evaluated for each of these systems with and without an energy recovery device (either a Pelton turbine or a pressure exchanger). The details on the process configurations are provided in Reference [56].

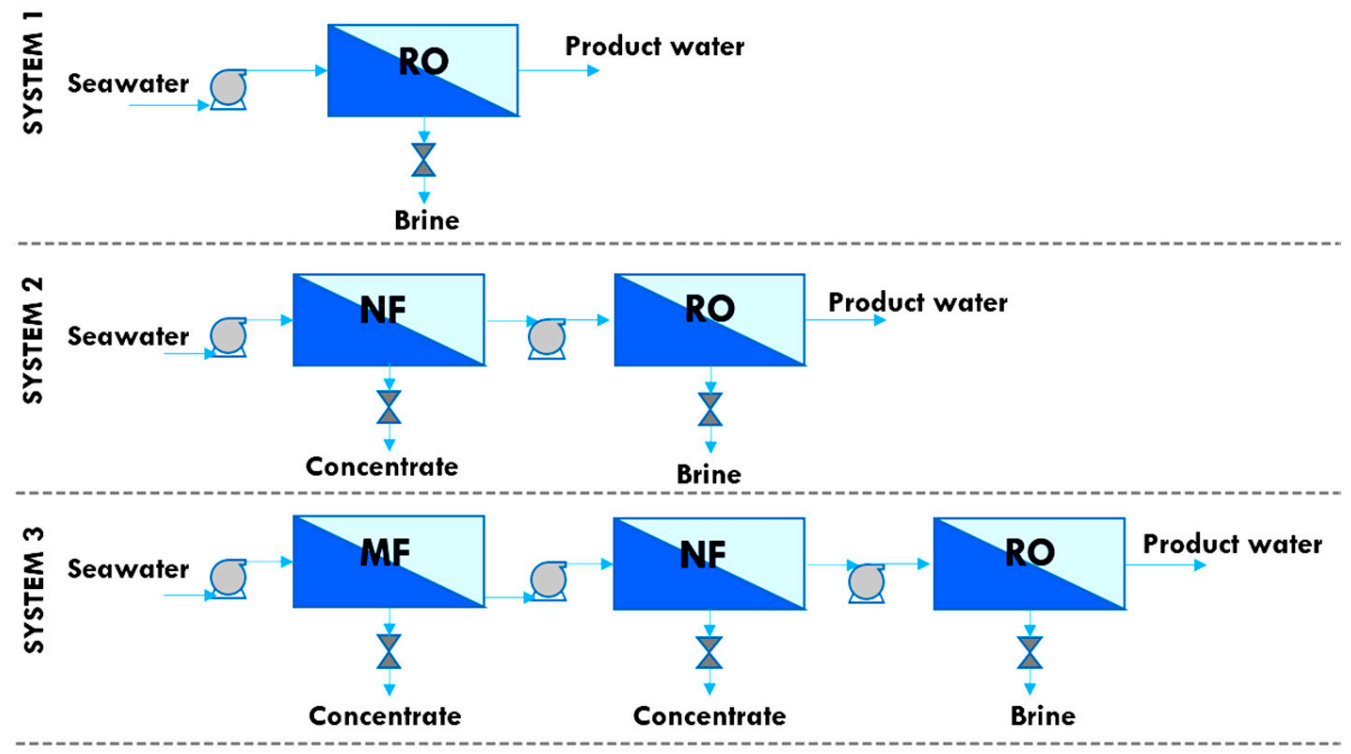

Figure 9. Schematics of integrated SWRO units without ERDs.

Table 5. Seawater flow rates, concentrations, and freshwater recovery efficiencies.

\begin{tabular}{cccc}
\hline & System $\mathbf{1}$ & System 2 & System 3 \\
\hline Process description & Direct RO & NF pretreatment + RO & MF + NF pretreatment + RO \\
Brine flow rate, $\mathrm{m}^{3} / \mathrm{h}$ & 629.9 & 504.5 & 531.9 \\
Brine concentration, $\mathrm{g} / \mathrm{L}$ & 57.6 & 71.9 & 68.0 \\
Fresh water flow rate, $\mathrm{m}^{3} / \mathrm{h}$ & 421.2 & 547.0 & 517.6 \\
Fresh water concentration, $\mathrm{g} / \mathrm{L}$ & 0.34 & 0.27 & 0.27 \\
Fresh water recovery, $\%$ & 40.1 & 52.0 & 49.2 \\
\hline
\end{tabular}

In the integrated processes, pretreatment through microfiltration and ultrafiltration units are included. The permeate recovery will be enhanced in the RO unit. However, the permeate quantity may be reduced due to losses in the microfiltration unit. Pretreatment reduces the biofouling and scaling issues in nanofiltration and $\mathrm{RO}$ units reducing maintenance and replacement costs. The permeate quality of the MF-NF-RO unit (System 3) was better than that for the NF-RO or RO units (Systems 2 and 1). The exergy efficiency results are shown in Figure 10. Introducing energy recovery units, either a Pelton turbine or pressure exchanger, increased the exergy efficiency of all systems. It should be noted that the exergy recovery for System 1 is higher than Systems 2 and 3 because the energy recovery device recovers the exergy from a higher brine flow compared to Systems 2 and 3. In comparison with thermal desalination systems, membrane desalination systems possess higher exergy efficiencies. Mehdizadeh [11] analyzed a mathematical model for multi-solute RO systems to determine the optimum operating condition for an integrated nanofiltration (NF)-reverse osmosis (RO) seawater desalination plant. The integrated NF-RO process produced higher product and less entropy (less rate of lost work or exergy losses). Table 6 presents a summary of different reverse osmosis process exergy efficiencies [53-59]. 


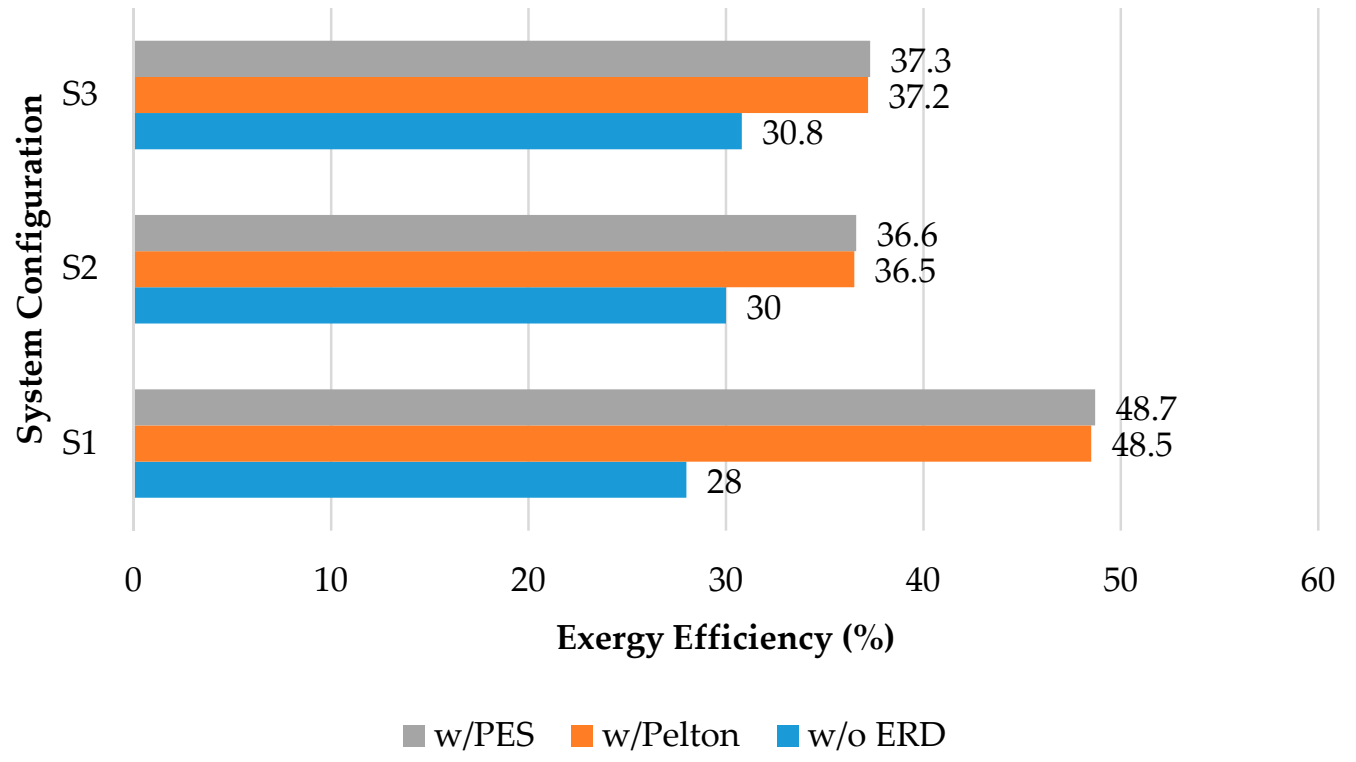

Figure 10. Exergy efficiencies of integrated SWRO units with and without ERDs.

Table 6. Exergy efficiency of reverse osmosis processes.

\begin{tabular}{cccc}
\hline Process & Capacity, $\mathbf{~ m}^{\mathbf{3}}$ /day & Exergy Efficiency, $\mathbf{\%}$ & Reference \\
\hline RO & 7250 & 4.3 & {$[53]$} \\
RO & 2850 & 0.7 & {$[57]$} \\
SWRO & 7586 & 5.8 & {$[58]$} \\
MF-NF-RO & 12,408 & 30.9 & {$[59]$} \\
\hline
\end{tabular}

\subsection{Solar Stills}

The essential components of a passive solar still are collector plate (absorber), saline water (brine), and glass cover. Passive systems collect solar energy incident on the glass cover directly to cause evaporation of pure water. The exergy efficiency of a passive solar system was reported at $5 \%$ [60]. The absorber had an exergy efficiency of $12.9 \%$ and the saline water had about $6 \%$. During non-sunlight hours, the sensible heat stored in the saline water causes further evaporation of freshwater due to lower ambient temperatures. The exergy efficiency of saline water during non-sunlight hours was reported as high as $93 \%$. In this study, the parameter of highest influence was found to be solar exergy input. An exergy destruction of $615 \mathrm{~W} / \mathrm{m}^{2}$ was noted for the collector out of a solar exergy input of $935 \mathrm{~W} / \mathrm{m}^{2}$ [60]. Increasing the number of effects in solar stills may improve the exergy efficiency. Sow et al. [61] reported exergy analysis of a single, double, and triple effect solar stills. Three important criteria were applied which were water rejection limit of 50\%, maximum salinity limit of $5.5 \%$, and a minimum solar energy utilization. The exergy efficiency of the triple effect system was between 19 and $26 \%$ and that of the double-effect system was between $17 \%$ and $20 \%$. The single-effect system had an exergy efficiency less than 4\% [61]. Energy storage may also improve the energy and exergy efficiencies in solar desalination systems [62,63]

A recent study by Ibrahim and Dincer [64] evaluated the exergy performance of a solar still with an external condenser similar to many other previous studies [65-68]. This comprehensive exergy analysis included rates of energy streams, exergy streams, exergy destructions, and improvement potentials. It was noted that higher solar energy absorption by the base as well as lower heat losses through solar still walls may increase the yields and thermodynamic performance of the solar still. They reported that increasing absorptivity of the basin by $12 \%$ (from 0.85 to 0.95 ) could result in enhancement of freshwater yield, energy and exergy efficiencies of the solar still by $27 \%, 25 \%$, and 
$39 \%$, respectively. Also by reducing the heat losses through the solar still by $75 \%$ may increase the freshwater yield and the second law efficiency by $87 \%$ and $152 \%$ respectively. Condenser was identified to contribute to major exergy losses. The energy and exergy efficiency of the solar still were $32.8 \%$ and $4 \%$ respectively [64].

Tiwari et al. [69] conducted a comparative study on the active and passive solar stills. The active solar still was supported by flat panel solar collectors while the passive still was standalone receiving direct solar energy. The aim of this modeling study was to compare the yields of the solar still for two cases with inner and outer glass cover temperatures being equal and unequal. The results showed that the freshwater yields were higher for the active solar still in both cases when compared with passive solar still. The yields for the active still were $3.08 \mathrm{~L}$ and $2.85 \mathrm{~L}$ for equal and unequal inner and outer glass cover temperatures respectively while the same for the passive solar still were $1.14 \mathrm{~L}$ and $1.09 \mathrm{~L}$, respectively. Furthermore, this study evaluated the effect of the number of solar collectors on the energy and exergy efficiencies of the active solar still. Since the depth of the saline water in the solar still would have significant effect on the process performance, calculations were performed at different saline water depths, as shown in Figure 11. A higher number of solar collectors resulted in lower energy and exergy efficiencies, while the optimum number of solar collectors was determined to be 3 . The depth of the saline water in the solar still also showed a negative effect on the energy and exergy efficiencies of the active solar still. Lower depth of saline water at about $5 \mathrm{~cm}$ was favorable in view of both the first law and second law efficiencies. Solar stills and similar configurations can be driven by low grade waste heat sources such as the heat rejected from domestic air-conditioning units and other industrial process waste heat sources [66,67]. A summary of studies focusing on exergy efficiency in solar stills is presented in Table 7 [60,64,70-77]. Several modifications of solar stills include single, double, and multi stage operation, active (with circulation or pumping) and passive still (without inclusion of any mechanical units), solar still design, shape and configurations, and integration with solar collectors or solar ponds. Other configurations include vacuum conditions in an evaporation chamber operated with direct solar energy, photovoltaic energy, and waste heat [78-80].

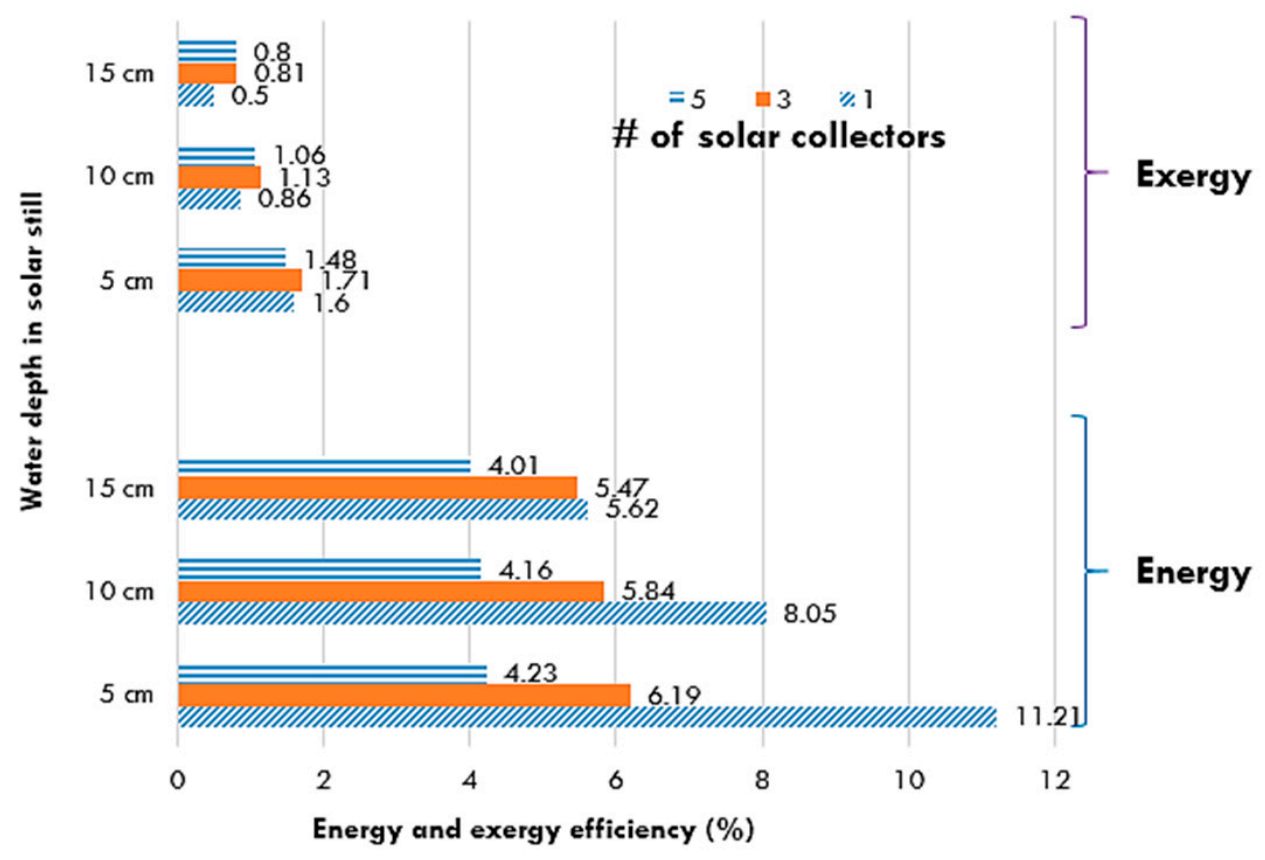

Figure 11. Energy and exergy of an active solar still with different saline water depths and optimum number of solar collectors. 
Table 7. Exergy efficiency in solar stills.

\begin{tabular}{|c|c|c|c|}
\hline Desalination Device & Description & Performance & Ref \\
\hline Passive solar still & $\begin{array}{l}\text { Exergy analysis of } \\
\text { individual compounds }\end{array}$ & $\begin{array}{l}\text { Collector-12.9\% } \\
\text { Brine-6.0\% } \\
\text { Solar still-5.0\% }\end{array}$ & [60] \\
\hline Passive solar still & $\begin{array}{l}\text { Single and Double slope } \\
\text { solar still }\end{array}$ & $\begin{array}{l}\text { Thermal Efficiency } \\
\text { Single-22.6-31.3\% } \\
\text { Double-25.4-34.3\% } \\
\text { Exergy Efficiency } \\
\text { Single-0.18-1.25\% } \\
\text { Double- } 0.13-1.16 \%\end{array}$ & [70] \\
\hline Passive solar still & Wind and insulation effects & $\begin{array}{l}\text { Max. exergy efficiency-9.48\% } \\
\text { Daily Avg. exergy efficiency—4.93\% } \\
\text { Exergy saved by Insulation- }-7.71 \%\end{array}$ & [71] \\
\hline \multirow{2}{*}{ Active solar still } & $\begin{array}{l}\text { Evaporator maintained } \\
\text { under vacuum with an } \\
\text { air-cooled condenser }\end{array}$ & $\begin{array}{l}\text { A } 12 \% \text { increase in basin absorptivity } \\
\text { increased distillate by } 27 \% \text {, energy utilization } \\
\text { by } 25 \% \text {, and exergy efficiency by } 39 \% \text {. }\end{array}$ & \multirow{2}{*}{ [64] } \\
\hline & $\begin{array}{l}\text { Effect of absorptivity of } \\
\text { basin and heat loss reduction } \\
\text { from basin walls }\end{array}$ & $\begin{array}{l}\text { A } 75 \% \text { reduction in basin heat losses } \\
\text { increased distillate production by } 87 \% \text { and } \\
\text { exergy performance by } 152 \% \text {. }\end{array}$ & \\
\hline Solar still with energy storage & $\begin{array}{l}\text { Phase change material } \\
\text { thermal storage }\end{array}$ & $\begin{array}{l}\text { Daytime exergy efficiency }<5 \% \\
\text { Nighttime exergy efficiency }>80 \%\end{array}$ & [72] \\
\hline Pyramid-shaped solar still & $\begin{array}{l}\text { Comparison of summer and } \\
\text { winter conditions, effect of } \\
\text { water depth }\end{array}$ & $\begin{array}{l}\text { No significant difference. Higher exergy } \\
\text { efficiency at a lower water depth }(4-8 \mathrm{~cm})\end{array}$ & [73] \\
\hline $\begin{array}{l}\text { Single-effect horizontal } \\
\text { basin-type passive solar stills }\end{array}$ & $\begin{array}{l}\text { Thermodynamic model } \\
\text { development }\end{array}$ & $\begin{array}{l}\text { Ultimate energy efficiency } 80.0 \% \\
\text { Optimum exergy efficiency } 21.1 \%\end{array}$ & [74] \\
\hline Weir type cascade solar still & $\begin{array}{l}\text { Computer simulation } \\
\text { package, effect of brine } \\
\text { flow rate }\end{array}$ & $\begin{array}{l}\text { Inlet brine flow rate of } 0.065 \mathrm{~kg} / \mathrm{min}-10.5 \% \\
\text { Inlet brine flow rate of } 0.2 \mathrm{~kg} / \mathrm{min}-3.14 \% \\
\text { High brine inlet flow rate- }-3.8-7.34 \%\end{array}$ & [75] \\
\hline $\begin{array}{l}\text { Thermoelectric assisted } \\
\text { solar still }\end{array}$ & $\begin{array}{l}\text { Dynamic thermodynamic } \\
\text { modeling study }\end{array}$ & $\begin{array}{l}\text { Energy efficiency-19.8\% } \\
\text { Exergy efficiency- } 0.95 \% \\
\text { Exergy destruction in thermo-electric } \\
\text { module- } 63.4 \%\end{array}$ & [76] \\
\hline Active solar still & $\begin{array}{l}\text { Solar still integrated with } \\
\text { solar pond }\end{array}$ & $\begin{array}{l}\text { Energy efficiency-38.6\% } \\
\text { Exergy efficiency-2.7\% }\end{array}$ & {$[77]$} \\
\hline
\end{tabular}

\subsection{Membrane Distillation}

Membrane distillation (MD) desalination processes provide unique opportunities for utilizing low grade heat sources generated from various sources such as a process waste heat or flat plate solar collectors. This process combines both the evaporation and separation component by incorporating the membrane separator to produce high quality permeates. This process can also be used to selectively remove various contaminants from a variety of impaired waters [81,82]. It is convenient to employ flat plate solar collectors or solar ponds to develop standalone membrane distillation units [83,84].

\subsubsection{Unit without a Heat Exchanger}

A small solar-powered MD desalination plant located in Irbid (Jordan) was studied [85]. The system consists of an MD module $\left(10 \mathrm{~m}^{2}\right)$, flat plate solar collectors $\left(6 \mathrm{~m}^{2}\right)$, a membrane pump, and a PV module (Figure 12). The energy demands for the MD process were provided by the solar collectors while the electrical energy demand was met by a PV panel. Feed water was first supplied through solar collectors for preheating. A spiral-wound air-gap membrane distillation module with internal heat recovery function was used. The plant capacity was approximately $120 \mathrm{~L} /$ day with a high distillate product. The specific heat energy required was $200-300 \mathrm{kWh} / \mathrm{m}^{3}$. The gained output ratio varied between 0.3 and 0.9 depending on daily solar insolation. 


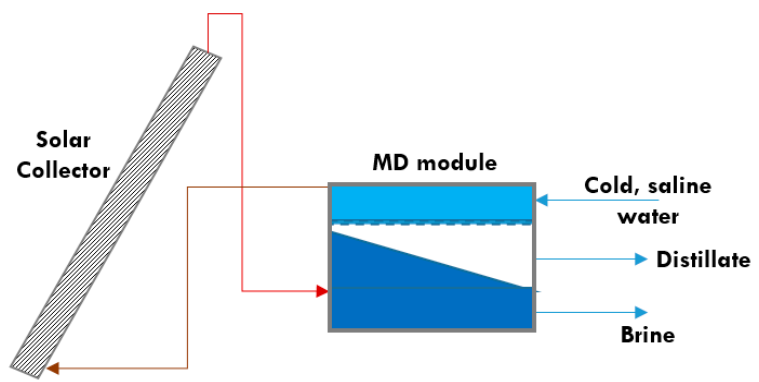

Figure 12. Flow schematic of a compact MD unit powered by solar collectors.

The exergy analysis of the MD unit is shown in Figure 13. This unit was fed by a brackish water source with a TDS of $3000 \mathrm{ppm}$ at a temperature of $308.15 \mathrm{~K}$ and $101.325 \mathrm{kPa}$ pressure. The exergy efficiency of the total system with reference to the exergy collected by the solar collector was $0.3 \%$ while the exergy efficiency of the total system with reference to the exergy of solar irradiance is $0.01 \%$ [86]. The solar collector alone had an exergy efficiency of $6.5 \%$. Within the MD unit, the major destruction occurred in the separation process, i.e., at the MD membrane with negligible exergy losses through the brine and distillate flows (Figure 13).

(a)

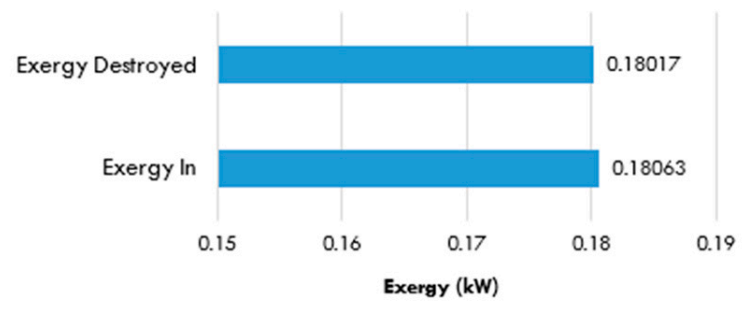

(b)

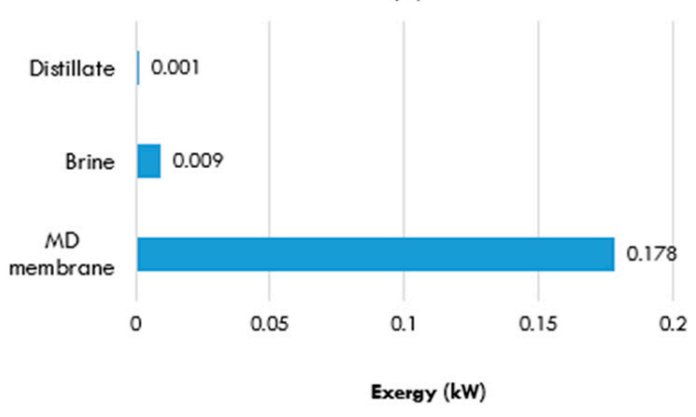

Figure 13. (a) Exergy balance of the solar powered MD unit without a heat exchanger; (b) exergy destruction in individual components.

\subsubsection{Unit with a Heat Exchanger}

As shown in Figure 14, this unit is considerably larger than the system without a heat exchanger unit [87]. It has four MD modules and a solar collector area of $72 \mathrm{~m}^{2}$ with a heat storage tank of $3 \mathrm{~m}^{3}$. This system has two separate loops called as collector loop which harvests the solar energy into the heat storage unit and the seawater loop of the MD desalination modules which extracts the heat from the storage tank. Similar to the previous system, thermal energy demands were met by solar thermal collectors at source temperatures of $60{ }^{\circ} \mathrm{C}$ to $80^{\circ} \mathrm{C}$. The heat storage tank served as a heat recovery system. The seawater withdrawn for desalination is about $279.15 \mathrm{~K}, 101.325 \mathrm{kPa}$, with a salinity of 40,000 ppm. The schematic of the MD unit is shown in Figure 15. Specific thermal energy consumption (energy required to produce unit distillate, expressed as $\mathrm{kWh} / \mathrm{m}^{3}$ ) for this unit was 
between $200 \mathrm{kWh} / \mathrm{m}^{3}$ and $300 \mathrm{kWh} / \mathrm{m}^{3}$. However, with energy recovery, new air-gap MD modules have achieved very low specific energy consumption.

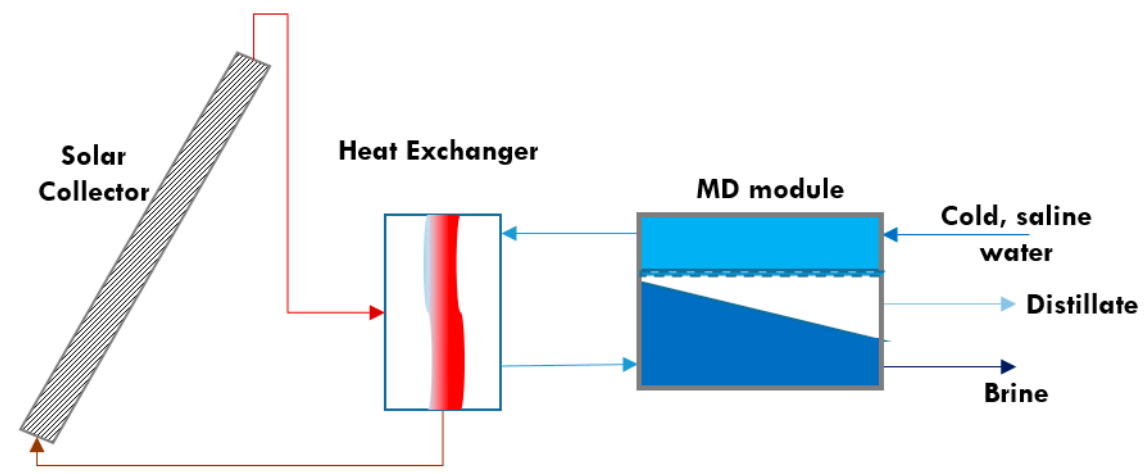

Figure 14. Flow schematic of an MD unit powered by solar collectors with a heat exchanger.
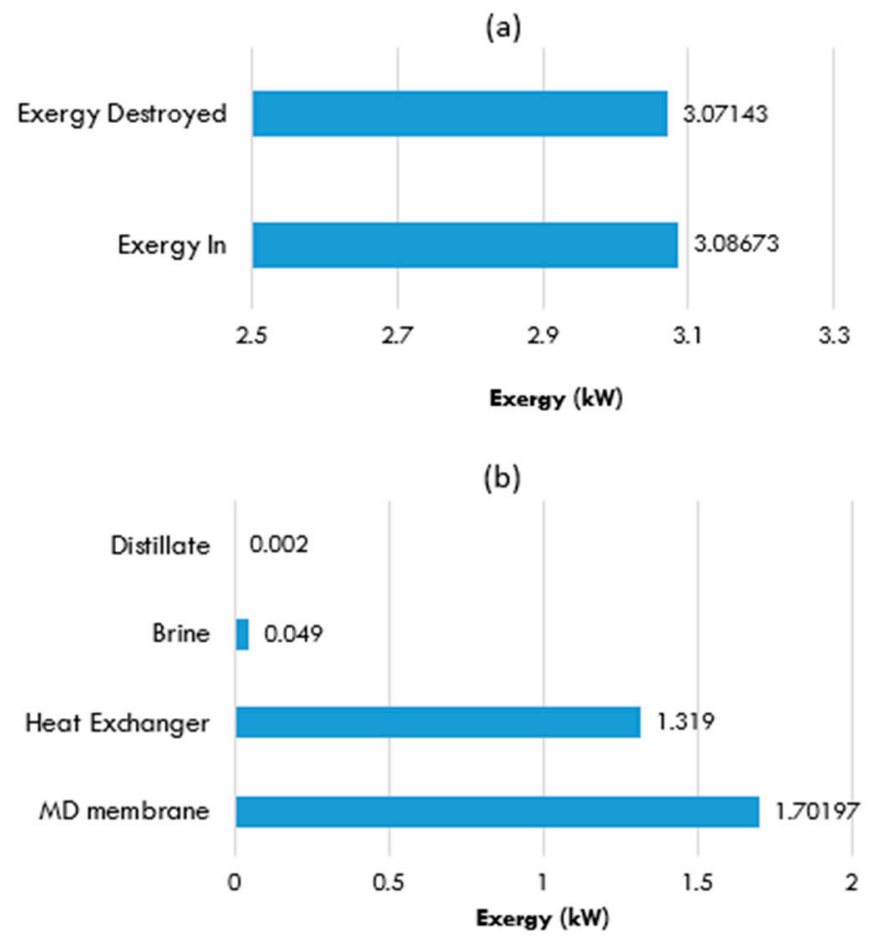

Figure 15. (a) Exergy balance of the solar powered MD unit with a heat exchanger; (b) exergy destruction in individual components.

The exergy evaluation of this process is shown in Figure 15. The exergy efficiency of the total system with reference to the exergy collected by the solar collector was $0.5 \%$ while the exergy efficiency of the total system with reference to the exergy of solar irradiance is $0.05 \%$. The solar collector alone had an exergy efficiency of 3\% less than the system without heat exchanger due to exergy losses from the heat exchanger. In this system, the MD unit accounts for nearly $55 \%$ of the exergy losses followed by almost $43 \%$ losses in the heat exchanger. The rest of the exergy losses are accounted for brine and distillate flows as shown in Figure 16. It was noted that by increasing the membrane surface area, the exergy recovery can be improved, thereby decreasing the exergy destruction albeit at a higher cost. It is ideal to utilize PV-thermal systems to provide for both thermal and electrical energy requirements for the MD desalination process. PV-thermal systems also have high energy efficiency $[62,88]$. Table 8 presents a summary of different membrane distillation process exergy efficiencies [59,86,89-91]. 

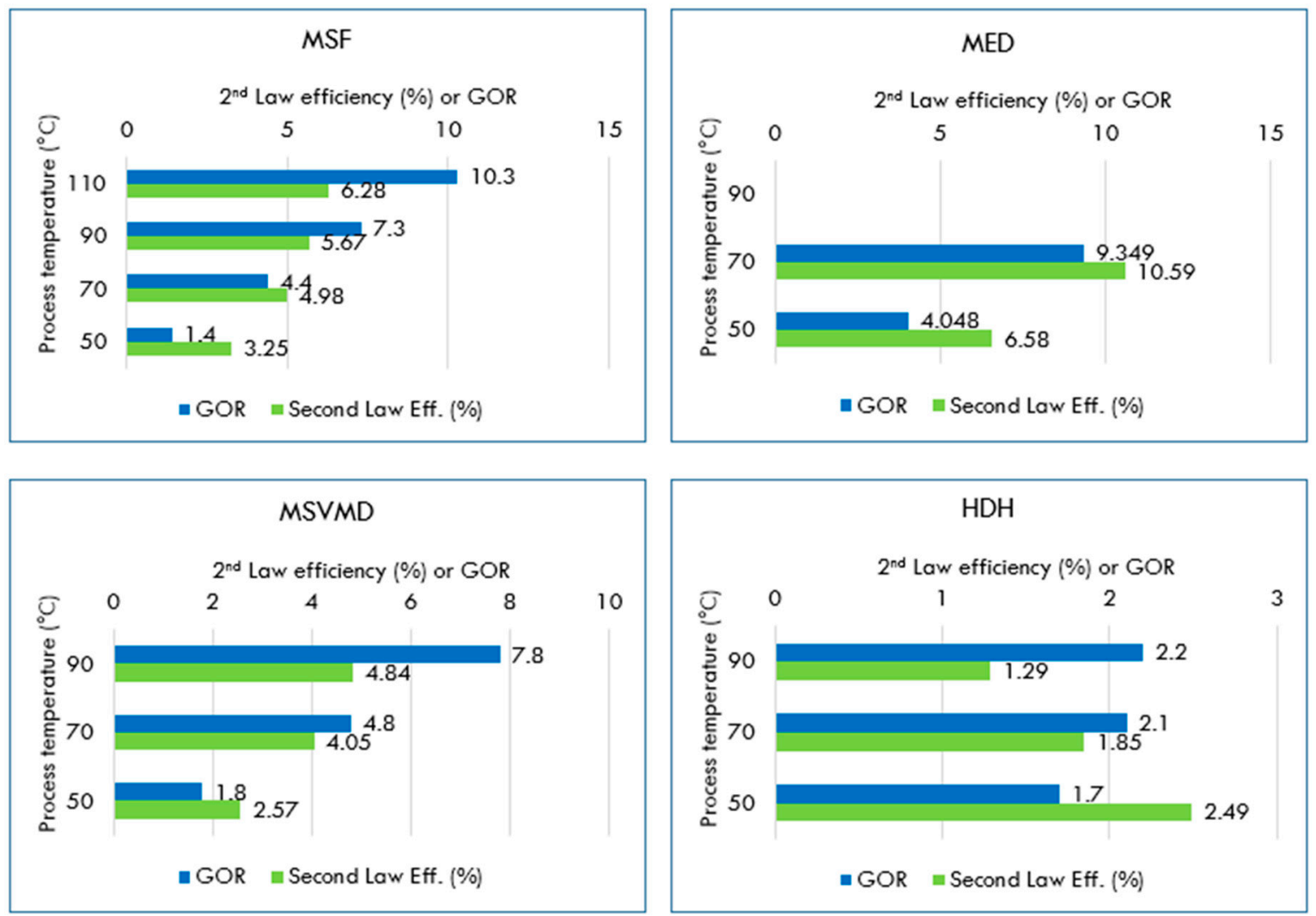

Figure 16. GOR and second law efficiencies in desalination processes based on entropy generation.

Table 8. A summary of different membrane distillation process exergy efficiencies.

\begin{tabular}{cccc}
\hline Process & Capacity, $\mathbf{~ m}^{\mathbf{3}}$ /day & Exergy Efficiency, $\%$ & Reference \\
\hline MD on RO retentate & 22,344 & $19.1-21.9$ & {$[59]$} \\
MD & 0.31 & 0.3 & {$[86]$} \\
DCMD with HR & 24,000 & 28.3 & {$[89]$} \\
DCMD without HR & 24,000 & 25.6 & {$[89]$} \\
AGMD (Xzero) & $0.22-0.73$ & $8.54-19.32$ & {$[89]$} \\
AGMD (Elixir500) & $0.1-0.17$ & $18.3-26.5$ & {$[90]$} \\
Solar powered VMD & 43 & 3.25 & {$[91]$} \\
Solar powered VMD & 43 & 0.18 & {$[91]$} \\
\hline
\end{tabular}

\subsection{Other Configurations}

Dual purpose power-water application is another way to increase the overall energy and exergy efficiencies. Combining power plants with thermal desalination systems in a cogeneration configuration is a well-known concept. Other types of integrated configurations involve a combination of a heat pump and a desalination unit. A double effect absorption heat pump was integrated to a multi-effect distillation (MED) unit powered by low temperature, medium temperature, and parabolic trough solar collector (PTC) systems [92]. The double effect absorption heat pump combined MED system powered by PTC resulted in the highest overall exergy efficiency of $4.3 \%$, followed by medium temperature PTC and low temperature solar collector systems with $2.0 \%$ and $1.1 \%$, respectively. As discussed earlier in Section 5.2, to increase the TBT-LBT range in a desalination process, hybrid desalination processes such as MED-AD (adsorption desalination) can be considered [37]. In a MED process combined with an $\mathrm{AD}$ process, the LBT of the hybrid process can be decreased from $35^{\circ} \mathrm{C}$ to $10^{\circ} \mathrm{C}$. This configuration allows for a higher number of stages, thus enabling higher product recovery. 
The low temperature operation also means that low grade heat sources can be employed which would otherwise be released into the environment without a purpose but to cause environmental issues.

\section{Entropy Generation in Desalination Processes}

The least work or heat of separation required for desalination processes must be determined to evaluate thermodynamic performance [22,78]. It is difficult to determine the performance of desalination processes when both heat and work are required for separation, as in the thermal desalination process. Processes that require work only for separation are MVC (mechanical vapor compression), $\mathrm{RO}$ (reverse osmosis), and ED (electrodialysis). The second law efficiency of desalination systems can be evaluated in terms of entropy generation [93]. A control volume analysis method can be used to estimate the entropy generation in a system defined by a control volume consisting of its entirety $[93,94]$.

All thermal desalination systems require both thermal and mechanical energy, and while chemical exergy is associated with mass flows, all need to be considered in a system analysis [93]. Source temperature is very important in determining the exergy efficiency of desalination processes. Second law efficiencies calculated by applying these equations are shown in Figure 16 for MSF (multistage flash), MED (multieffect distillation), MSVMD (multistage vacuum membrane distillation), and HDH (humidification and dehumidification) processes. Gained output ratios are also shown in Figure 16 [95]. Although the gained output ratio increases with an increase in heat source temperature in MSF, MED, and MSVMD processes, the trend in the humidification and dehumidification process is different, as shown in Figure 16. This is because the HDH process depends on various conditions such as the ambient air temperature and the moisture content of the air.

\section{Desalination Exergy Costs (Thermoeconomics)}

Thermoeconomics, or exergy costs, analysis accounts for the consumption of input resources into an energy system that produces a product. Each of these systems consumes resources in a variation mainly due to the fact that each system involves a different number of processes along with their efficiencies [51,96]. Exergy cost analysis reveals that a process with a low exergy performance may requires a high exergy input, therefore, indicating a higher consumption of external resources and a higher production cost. In this context, the thermoeconomic cost of a product is defined as those costs required to produce a unit exergy of the reference product. In systems with multiple products, the thermoeconomic cost is attributed to the product that involves the highest exergy destruction. Uche et al. [86] studied the exergy costs of a dual power and desalination plant considering six different configurations. It was reported that the dual plant exergy costs are strongly influenced by the final cost of the desalinated water and electricity. The inefficiency diagnosis performed in this study also highlights that the exergy costs analysis not only evaluates penalties due to inefficiencies but also allows discovery of the relationships between the inefficiencies and economic penalties. Another example that emphasizes the use of exergy costs analysis is that in desalination process analysis, in general, the exergy associated with the steam produced in the last product across the processes (MSF and MED) is considered to have the same quality. In a similar way, the steam supplied as a heat source in these processes is often considered to have same exergy value (or quality), but this is not true. For MED, the steam supplied initially and that finally released are quite different in their ability to produce work when compared with the steam supplied and that released by an MSF unit. Considering this issue, $\mathrm{Ng}$ et al. [37] performed an exergy cost analysis using the actual quality of the steam supplied in each of the processes. In general, about $20 \%$ of the steam fed to the MSF and MED processes is released as the bleed steam in the last effect. Considering this ratio, the energy and exergy costs of plants combined with power generation were calculated. As shown in Figure 17, the exergy costs of the desalination processes are lower than the energy costs which represent the true costs of resources to be supplied into the system to produce freshwater as a product. A similar observation was reported in a study considering the exergetic (thermo-economic) optimization of an 
MED process, confirming the role of thermodynamic evaluation in optimizing the process parameters and product costs [97].

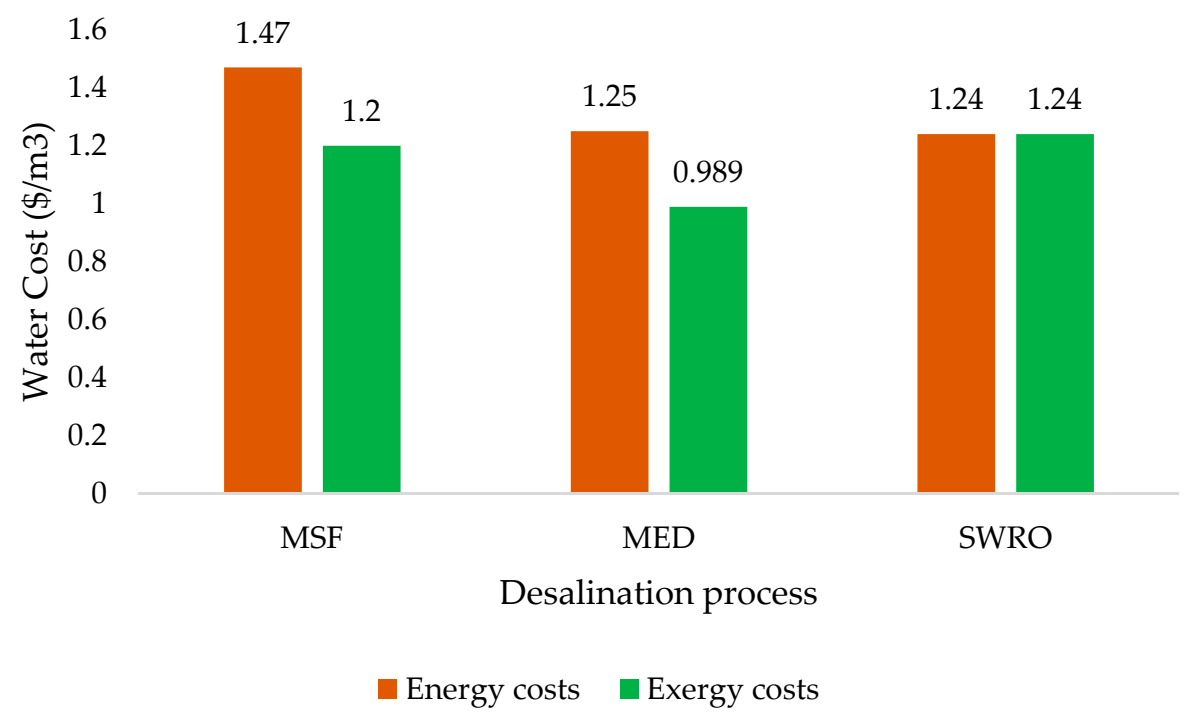

Figure 17. Comparison of energy and exergy costs of common desalination processes.

\section{Concluding Remarks}

Exergy analysis provides insight into the thermodynamic losses in desalination systems. This method is instrumental in identifying the key process units that are responsible for major exergy destruction. This information can be used to modify process configurations to optimize the exergy performance.

For thermal desalination systems, the exergy losses occur in condensers where the latent heat is lost to the environment or rejected to the cooling water. This is one area of consideration for better recovery and utilization of exergy. Brine circulation, heat recovery from brine discharges, and integration with heat pumps and other power generation systems are alternatives for increasing the exergy performance.

For membrane systems, the membrane barrier itself is the major exergy destructor and the improvements have almost reached thermodynamic efficiency through high permeability and low energy consuming membranes. However, integrating membrane processes with power generation or thermal desalination processes can be an attractive approach from an exergy point of view.

High exergy costs of heat sources should be minimized as much as possible. It is also advisable to utilize high exergy sources for higher quality product development. Heat pumps, absorption, and double stage heat pumps combined with thermal processes are attractive options for utilizing solar energy. From the case studies described here, it can be stated that for desalination purposes, considering the unavoidable destruction in both membrane and thermal systems, low exergy sources should be utilized as driving forces where possible. This may lead to efficient utilization of available energy resources for sustainable environmental and process development. It should also be noted that all cogeneration schemes involving power and water production are not entirely favorable. From an exergy point of view, power generation and membrane desalination system combination is more exergetically favorable when compared with thermal systems, despite the low exergy resource input.

Acknowledgments: This work was partially supported by research funds from New Mexico Water Resources Research Institute (NM WRRI) and USEPA.

Conflicts of Interest: The authors declare no conflict of interest. 


\section{Nomenclature}

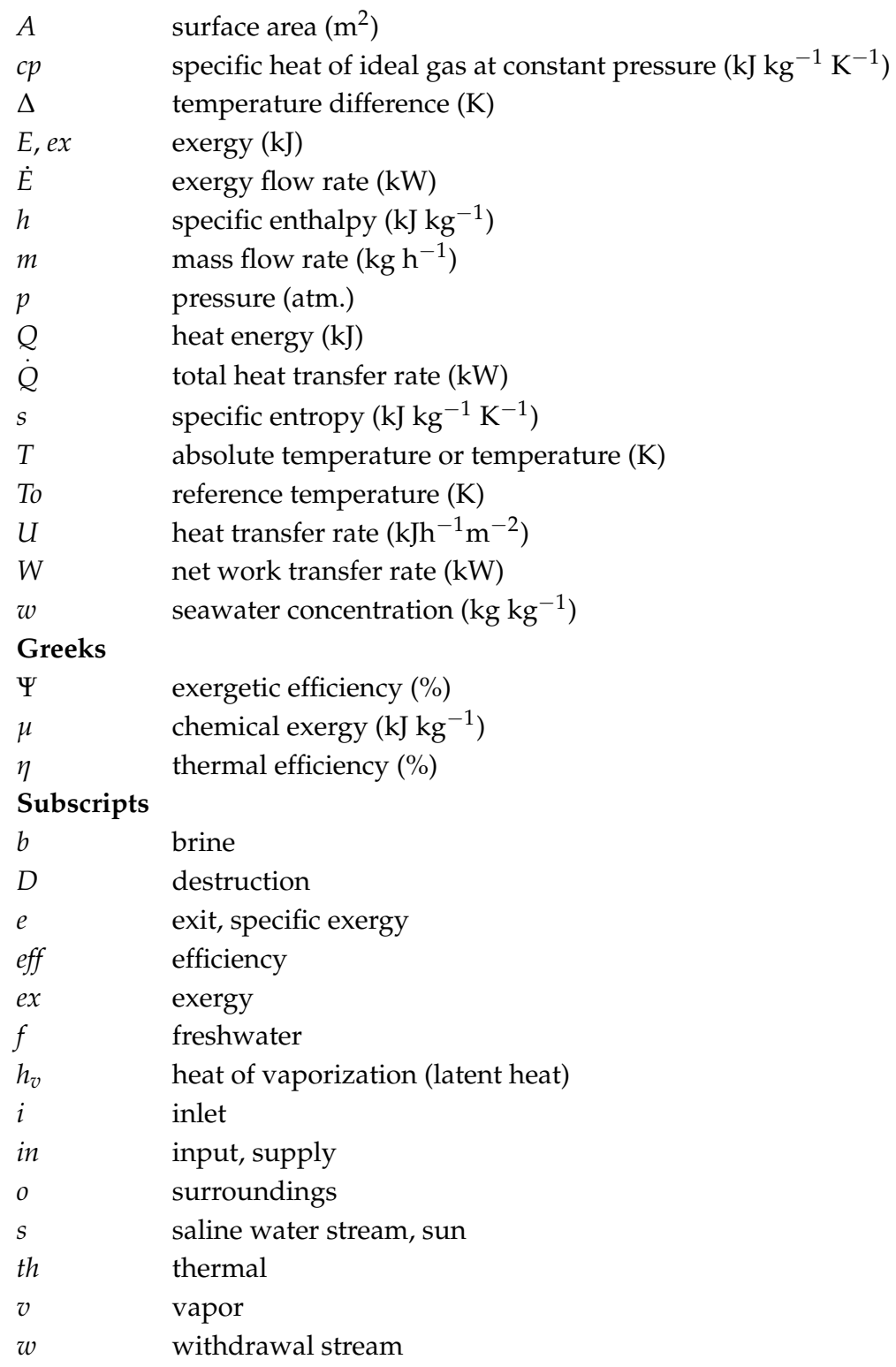

\section{References}

1. Gude, V.G.; Nirmalakhandan, N.; Deng, S. Renewable and sustainable approaches for desalination. Renew. Sustain. Energy Rev. 2010, 14, 2641-2654. [CrossRef]

2. Gude, V.G. Energy storage for desalination processes powered by renewable energy and waste heat sources. Appl. Energy 2015, 137, 877-898. [CrossRef]

3. Gude, V.G. Desalination of deep groundwater aquifers for freshwater supplies-Challenges and strategies. Groundw. Sustain. Dev. 2018, 6, 87-92. [CrossRef]

4. Gude, V.G. Desalination and sustainability-An appraisal and current perspective. Water Res. 2016, 89, 87-106. [CrossRef] [PubMed]

5. Gude, V.G. Desalination and water reuse to address global water scarcity. Rev. Environ. Sci. Bio/Technol. 2017, 16, 591-609. [CrossRef]

6. Kotas, T.J. The Exergy Method of Thermal Plant Analysis; Elsevier: New York, NY, USA, 2013.

7. Sandnes, B. Exergy Efficient Production, Storage and Distribution of Solar Energy. Ph.D. Thesis, University of Oslo, Oslo, Norway, 2003. 
8. Hepbasli, A. A key review on exergetic analysis and assessment of renewable energy resources for a sustainable future. Renew. Sustain. Energy Rev. 2008, 12, 593-661. [CrossRef]

9. Gude, V.G.; Nirmalakhandan, N.; Deng, S.; Maganti, A. Desalination at low temperatures: An exergy analysis. Desalin. Water Treat. 2012, 40, 272-281. [CrossRef]

10. Drioli, E.; Laganà, F.; Criscuoli, A.; Barbieri, G. Integrated membrane operations in desalination processes. Desalination 1999, 122, 141-145. [CrossRef]

11. Mehdizadeh, H. Membrane desalination plants from an energy-exergy viewpoint. Desalination 2006, 191, 200-209. [CrossRef]

12. Martínez, A.; Uche, J.; Rubio, C.; Carrasquer, B. Exergy cost of water supply and water treatment technologies. Desalin. Water Treat. 2010, 24, 123-131. [CrossRef]

13. Mabrouk, A.N.A.; Nafey, A.S.; Fath, H.E. Steam, electricity and water costs evaluation of power desalination co-generation plants. Desalin. Water Treat. 2010, 22, 56-64. [CrossRef]

14. Göğüş, Y.A.; Çamdalı, Ü.; Kavsaoğlu, M.Ş. Exergy balance of a general system with variation of environmental conditions and some applications. Energy 2002, 27, 625-646. [CrossRef]

15. Nisan, S. Utilisation of the exergy method for the cost evaluation of integrated nuclear desalination systems. Desalin. Water Treat. 2009, 8, 225-235. [CrossRef]

16. Narayan, G.P.; Sharqawy, M.H.; Lienhard, V.J.H.; Zubair, S.M. Thermodynamic analysis of humidification dehumidification desalination cycles. Desalin. Water Treat. 2010, 16, 339-353. [CrossRef]

17. Ucar, A.; Inalli, M. Thermal and exergy analysis of solar air collectors with passive augmentation techniques. Int. Commun. Heat Mass Transf. 2006, 33, 1281-1290. [CrossRef]

18. Mistry, K.H.; Lienhard, J.H.; Zubair, S.M. Effect of entropy generation on the performance of humidification-dehumidification desalination cycles. Int. J. Therm. Sci. 2010, 49, 1837-1847. [CrossRef]

19. Molinari, R.; Gagliardi, R.; Drioli, E. Methodology for estimating saving of primary energy with membrane operations in industrial processes. Desalination 1995, 100, 125-137. [CrossRef]

20. Gude, V.G.; Nirmalakhandan, N.; Deng, S. Desalination using solar energy: Towards sustainability. Energy 2011, 36, 78-85. [CrossRef]

21. Gundersen, T. An Introduction to the Concept of Exergy and Energy Quality; Lecture Notes; Norwegian University of Science and Technology: Trondheim, Norway, 2011.

22. Sciubba, E.; Wall, G. A brief commented history of exergy from the beginnings to 2004. Int. J. Thermodyn. 2007, 10, 1-26.

23. Sharqawy, M.H.; Zubair, S.M. On exergy calculations of seawater with applications in desalination systems. Int. J. Therm. Sci. 2011, 50, 187-196. [CrossRef]

24. Bejan, A.; Tsatsaronis, G.; Moran, M.J. Thermal Design and Optimization; John Wiley \& Sons: Hoboken, NJ, USA, 1996.

25. Petela, R. Exergy of undiluted thermal radiation. Sol. Energy 2003, 74, 469-488. [CrossRef]

26. Ng, K.C.; Shahzad, M.W.; Son, H.S.; Hamed, O.A. An exergy approach to efficiency evaluation of desalination. Appl. Phys. Lett. 2017, 110, 184101. [CrossRef]

27. Carrasquer, B.; Martínez-Gracia, A.; Uche, J. Exergy costs analysis of water desalination and purification techniques by transfer functions. Energy Convers. Manag. 2016, 126, 51-59. [CrossRef]

28. Spiegler, K.S.; El-Sayed, Y. The energetics of desalination processes. Desalination 2001, 134, $109-128$. [CrossRef]

29. Kahraman, N.; Cengel, Y.A. Exergy analysis of a MSF distillation plant. Energy Convers. Manag. 2005, 46, 2625-2636. [CrossRef]

30. Ersayin, E.; Ozgener, L. Performance analysis of combined cycle power plants: A case study. Renew. Sustain. Energy Rev. 2015, 43, 832-842. [CrossRef]

31. Nafey, A.S.; Fath, H.E.S.; Mabrouk, A.A. Exergy and thermoeconomic evaluation of MSF process using a new visual package. Desalination 2006, 201, 224-240. [CrossRef]

32. Najafi, B.; Shirazi, A.; Aminyavari, M.; Rinaldi, F.; Taylor, R.A. Exergetic, economic and environmental analyses and multi-objective optimization of an SOFC-gas turbine hybrid cycle coupled with an MSF desalination system. Desalination 2014, 334, 46-59. [CrossRef]

33. Al-Weshahi, M.A.; Anderson, A.; Tian, G. Exergy efficiency enhancement of MSF desalination by heat recovery from hot distillate water stages. Appl. Therm. Eng. 2013, 53, 226-233. [CrossRef] 
34. Al-Sulaiman, F.A.; Ismail, B. Exergy analysis of major recirculating multi-stage flash desalting plants in Saudi Arabia. Desalination 1995, 103, 265-270. [CrossRef]

35. García-Rodríguez, L.; Gómez-Camacho, C. Exergy analysis of the SOL-14 plant (Plataforma Solar de Almeria, Spain). Desalination 2001, 137, 251-258. [CrossRef]

36. Nafey, A.S.; Fath, H.E.S.; Mabrouk, A.A. Thermo-economic investigation of multi effect evaporation (MEE) and hybrid multi effect evaporation-Multi stage flash (MEE-MSF) systems. Desalination 2006, 201, 241-254. [CrossRef]

37. Ng, K.C.; Thu, K.; Oh, S.J.; Ang, L.; Shahzad, M.W.; Ismail, A.B. Recent developments in thermally-driven seawater desalination: Energy efficiency improvement by hybridization of the MED and AD cycles. Desalination 2015, 356, 255-270. [CrossRef]

38. Sayyaadi, H.; Saffari, A.; Mahmoodian, A. Various approaches in optimization of multi effects distillation desalination systems using a hybrid meta-heuristic optimization tool. Desalination 2010, 254, 138-148. [CrossRef]

39. Hamed, O.A. Thermoeconomic analysis of combined power cycle integrated with MSF/SWRO desalination plant. Desalin. Water Treat. 2016, 57, 26552-26561. [CrossRef]

40. Hamed, O.A.; Zamamiri, A.M.; Aly, S.; Lior, N. Thermal performance and exergy analysis of a thermal vapor compression desalination system. Energy Convers. Manag. 1996, 37, 379-387. [CrossRef]

41. Al-Najem, N.M.; Darwish, M.A.; Youssef, F.A. Thermovapor compression desalters: Energy and availability-Analysis of single-and multi-effect systems. Desalination 1997, 110, 223-238. [CrossRef]

42. Alasfour, F.N.; Darwish, M.A.; Amer, A.B. Thermal analysis of ME-TVC+ MEE desalination systems. Desalination 2005, 174, 39-61. [CrossRef]

43. Choi, H.S.; Lee, T.J.; Kim, Y.G.; Song, S.L. Performance improvement of multiple-effect distiller with thermal vapor compression system by exergy analysis. Desalination 2005, 182, 239-249. [CrossRef]

44. Samaké, O.; Galanis, N.; Sorin, M. Thermodynamic study of multi-effect thermal vapour-compression desalination systems. Energy 2014, 72, 69-79. [CrossRef]

45. Esfahani, I.J.; Ataei, A.; Shetty, V.; Oh, T.; Park, J.H.; Yoo, C. Modeling and genetic algorithm-based multi-objective optimization of the MED-TVC desalination system. Desalination 2012, 292, 87-104. [CrossRef]

46. Eshoul, N.M.; Agnew, B.; Mnider, A.M. Parametric study of mult-effect desalination with thermal vapour compression plant. In Proceedings of the 2016 7th International Renewable Energy Congress (IREC), Hammamet, Tunisia, 22-24 March 2016; pp. 1-6.

47. Carballo, J.A.; Bonilla, J.; Roca, L.; De la Calle, A.; Palenzuela, P.; Alarcón-Padilla, D.C. Optimal operating conditions analysis for a multi-effect distillation plant according to energetic and exergetic criteria. Desalination 2018, 435, 70-76. [CrossRef]

48. Piacentino, A. Application of advanced thermodynamics, thermoeconomics and exergy costing to a Multiple Effect Distillation plant: In-depth analysis of cost formation process. Desalination 2015, 371, 88-103. [CrossRef]

49. Nafey, A.S.; Fath, H.E.S.; Mabrouk, A.A. Thermoeconomic design of a multi-effect evaporation mechanical vapor compression (MEE-MVC) desalination process. Desalination 2008, 230, 1-15. [CrossRef]

50. Mabrouk, A.A.; Nafey, A.S.; Fath, H.E.S. Thermoeconomic analysis of some existing desalination processes. Desalination 2007, 205, 354-373. [CrossRef]

51. Catrini, P.; Cipollina, A.; Micale, G.; Piacentino, A.; Tamburini, A. Exergy analysis and thermoeconomic cost accounting of a Combined Heat and Power steam cycle integrated with a Multi Effect Distillation-Thermal Vapour Compression desalination plant. Energy Convers. Manag. 2017, 149, 950-965. [CrossRef]

52. Mokhtari, H.; Sepahvand, M. Thermoeconomic and exergy analysis in using hybrid systems (GT+ MED+ RO) for desalination of brackish water in Persian Gulf. Desalination 2016, 399, 1-15. [CrossRef]

53. Cerci, Y. Exergy analysis of a reverse osmosis desalination plant in California. Desalination 2002, 142, $257-266$. [CrossRef]

54. Aljundi, I.H. Second-law analysis of a reverse osmosis plant in Jordan. Desalination 2009, 239, $207-215$. [CrossRef]

55. Romero-Ternero, V.; García-Rodríguez, L.; Gómez-Camacho, C. Exergy analysis of a seawater reverse osmosis plant. Desalination 2005, 175, 197-207. [CrossRef]

56. Macedonio, F.; Curcio, E.; Drioli, E. Integrated membrane systems for seawater desalination: Energetic and exergetic analysis, economic evaluation, experimental study. Desalination 2007, 203, 260-276. [CrossRef] 
57. Ameri, M.; Eshaghi, M.S. A novel configuration of reverse osmosis, humidification-dehumidification and flat plate collector: Modeling and exergy analysis. Appl. Therm. Eng. 2016, 103, 855-873. [CrossRef]

58. El-Emam, R.S.; Dincer, I. Thermodynamic and thermoeconomic analyses of seawater reverse osmosis desalination plant with energy recovery. Energy 2014, 64, 154-163. [CrossRef]

59. Drioli, E.; Curcio, E.; Di Profio, G.; Macedonio, F.; Criscuoli, A. Integrating membrane contactors technology and pressure-driven membrane operations for seawater desalination: Energy, exergy and costs analysis. Chem. Eng. Res. Des. 2006, 84, 209-220. [CrossRef]

60. Torchia-Nunez, J.C.; Porta-Gandara, M.A.; Cervantes-de Gortari, J.G. Exergy analysis of a passive solar still. Renew. Energy 2008, 33, 608-616. [CrossRef]

61. Sow, O.; Siroux, M.; Desmet, B. Energetic and exergetic analysis of a triple-effect distiller driven by solar energy. Desalination 2005, 174, 277-286. [CrossRef]

62. Gude, V.G.; Nirmalakhandan, N.; Deng, S. Integrated PV-thermal system for desalination and power production. Desalin. Water Treat. 2011, 36, 129-140. [CrossRef]

63. Gude, V.G.; Nirmalakhandan, N.; Deng, S.; Maganti, A. Low temperature desalination using solar collectors augmented by thermal energy storage. Appl. Energy 2012, 91, 466-474. [CrossRef]

64. Ibrahim, A.G.; Dincer, I. A solar desalination system: Exergetic performance assessment. Energy Convers. Manag. 2015, 101, 379-392. [CrossRef]

65. Al-Kharabsheh, S.; Goswami, D.Y. Analysis of an innovative water desalination system using low-grade solar heat. Desalination 2003, 2003, 323-332. [CrossRef]

66. Gude, V.G.; Nirmalakhandan, N. Desalination using low-grade heat sources. ASCE J. Energy Eng. 2008, 134, 95-101. [CrossRef]

67. Gude, V.G.; Nirmalakhandan, N. Combined desalination and solar-assisted air-conditioning system. Energy Convers. Manag. 2008, 49, 3326-3330. [CrossRef]

68. Gude, V.G.; Nirmalakhandan, N.; Deng, S. Sustainable low temperature desalination: A case for renewable energy. J. Renew. Sustain. Energy 2011, 3, 043108. [CrossRef]

69. Tiwari, G.N.; Dimri, V.; Chel, A. Parametric study of an active and passive solar distillation system: Energy and exergy analysis. Desalination 2009, 242, 1-18. [CrossRef]

70. Dwivedi, V.K.; Tiwari, G.N. Annual energy and exergy analysis of single and double slope passive solar stills. Trends Appl. Sci. Res. 2008, 3, 225-241.

71. Ranjan, K.R.; Kaushik, S.C.; Panwar, N.L. Energy and exergy analysis of passive solar distillation systems. Int. J. Low-Carbon Technol. 2016, 11, 211-221. [CrossRef]

72. Asbik, M.; Ansari, O.; Bah, A.; Zari, N.; Mimet, A.; El-Ghetany, H. Exergy analysis of solar desalination still combined with heat storage system using phase change material (PCM). Desalination 2016, 381, $26-37$. [CrossRef]

73. Kianifar, A.; Heris, S.Z.; Mahian, O. Exergy and economic analysis of a pyramid-shaped solar water purification system: Active and passive cases. Energy 2012, 38, 31-36. [CrossRef]

74. Kaushik, S.C.; Ranjan, K.R.; Panwar, N.L. Optimum exergy efficiency of single-effect ideal passive solar stills. Energy Effic. 2013, 6, 595-606. [CrossRef]

75. Zoori, H.A.; Tabrizi, F.F.; Sarhaddi, F.; Heshmatnezhad, F. Comparison between energy and exergy efficiencies in a weir type cascade solar still. Desalination 2013, 325, 113-121. [CrossRef]

76. Dehghan, A.A.; Afshari, A.; Rahbar, N. Thermal modeling and exergetic analysis of a thermoelectric assisted solar still. Sol. Energy 2015, 115, 277-288. [CrossRef]

77. Ranjan, K.R.; Kaushik, S.C. Exergy analysis of the active solar distillation systems integrated with solar ponds. Clean Technol. Environ. Policy 2014, 16, 791-805. [CrossRef]

78. Gude, V.G.; Mummaneni, A.; Nirmalakhandan, N. Emergy, energy and exergy analysis of a solar powered low temperature desalination system. Desalin. Water Treat. 2017, 74, 21-34. [CrossRef]

79. Gude, V.G.; Nirmalakhandan, N. Desalination at low temperatures and low pressures. Desalination 2009, 244, 239-247. [CrossRef]

80. Gude, V.G.; Nirmalakhandan, N.; Deng, S.; Maganti, A. Feasibility study of a new two-stage low temperature desalination process. Energy Convers. Manag. 2012, 56, 192-198. [CrossRef]

81. Yarlagadda, S.; Gude, V.G.; Camacho, L.M.; Pinappu, S.; Deng, S. Potable water recovery from As, U, and F contaminated ground waters by direct contact membrane distillation process. J. Hazard. Mater. 2011, 192, 1388-1394. [CrossRef] [PubMed] 
82. Yarlagadda, S.; Camacho, L.M.; Gude, V.G.; Wei, Z.; Deng, S. Membrane distillation for desalination and other separations. Recent Pat. Chem. Eng. 2009, 2, 128-158. [CrossRef]

83. Qtaishat, M.R.; Banat, F. Desalination by solar powered membrane distillation systems. Desalination 2013, 308, 186-197. [CrossRef]

84. Saffarini, R.B.; Summers, E.K.; Arafat, H.A. Economic evaluation of stand-alone solar powered membrane distillation systems. Desalination 2012, 299, 55-62. [CrossRef]

85. Banat, F.; Jwaied, N.; Rommel, M.; Koschikowski, J.; Wieghaus, M. Desalination by a "compact SMADES" autonomous solarpowered membrane distillation unit. Desalination 2007, 217, 29-37. [CrossRef]

86. Banat, F.; Jwaied, N. Exergy analysis of desalination by solar-powered membrane distillation units. Desalination 2008, 230, 27-40. [CrossRef]

87. Banat, F.; Jwaied, N.; Rommel, M.; Koschikowski, J.; Wieghaus, M. Performance evaluation of the "large SMADES" autonomous desalination solar-driven membrane distillation plant in Aqaba, Jordan. Desalination 2007, 217, 17-28. [CrossRef]

88. Chow, T.T.; Pei, G.; Fong, K.F.; Lin, Z.; Chan, A.L.S.; Ji, J. Energy and exergy analysis of photovoltaic-thermal collector with and without glass cover. Appl. Energy 2009, 86, 310-316. [CrossRef]

89. Al-Obaidani, S.; Curcio, E.; Macedonio, F.; Di Profio, G.; Al-Hinai, H.; Drioli, E. Potential of membrane distillation in seawater desalination: Thermal efficiency, sensitivity study and cost estimation. J. Membr. Sci. 2008, 323, 85-98. [CrossRef]

90. Woldemariam, D.; Martin, A.; Santarelli, M. Exergy analysis of air-gap membrane distillation systems for water purification applications. Appl. Sci. 2017, 7, 301. [CrossRef]

91. Miladi, R.; Frikha, N.; Gabsi, S. Exergy analysis of a solar-powered vacuum membrane distillation unit using two models. Energy 2017, 120, 872-883. [CrossRef]

92. Alarcón-Padilla, D.C.; García-Rodríguez, L. Application of absorption heat pumps to multi-effect distillation: A case study of solar desalination. Desalination 2007, 212, 294-302. [CrossRef]

93. Mistry, K.H.; Lienhard, J.H. Generalized least energy of separation for desalination and other chemical separation processes. Entropy 2013, 15, 2046-2080. [CrossRef]

94. Mistry, K.H.; McGovern, R.K.; Thiel, G.P.; Summers, E.K.; Zubair, S.M.; Lienhard, V.J.H. Entropy generation analysis of desalination technologies. Entropy 2011, 13, 1829-1864. [CrossRef]

95. Warsinger, D.M.; Mistry, K.H.; Nayar, K.G.; Chung, H.W.; Lienhard, V.J.H. Entropy generation of desalination powered by variable temperature waste heat. Entropy 2015, 17, 7530-7566. [CrossRef]

96. Uche, J.; Serra, L.; Valero, A. Exergy costs and inefficiency diagnosis of a dual-purpose power and desalination plant. J. Energy Resour. Technol. 2006, 128, 186-193. [CrossRef]

97. Sayyaadi, H.; Saffari, A. Thermoeconomic optimization of multi effect distillation desalination systems. Appl. Energy 2010, 87, 1122-1133. [CrossRef] 